Journal of Urban and Regional Analysis, vol. XI, 2, 2019, p. $113-157$

https://doi.org/10.37043/JURA.2019.11.2.2

\title{
COMPOSITE INDEX TO MEASURE THE PERFORMANCE OF TODAY'S CREATIVE CITIES: A HOLISTIC PERSPECTIVE
}

\author{
Margarida RODRIGUES, Mário FRANCO \\ University of Beira Interior, Covilhã, Portugal
}

\begin{abstract}
The urgency to make today's cities competitive has made political decisionmakers focus on strategies oriented towards creativity, intelligence and urban sustainability. This scenario has led to the need to measure, assess and monitor the effects of those strategies on cities' performance. Therefore, this study aims to present the scientific and robust weighting of the creativity, intelligence and urban sustainability dimensions in cities' holistic, integrated and overall performance. Implicit in this objective is the previous construction of Composite Indices for each of those dimensions. In this context, the Exploratory Factor Analysis was found to be appropriate to respond to this aim, with empirical evidence being obtained in Portugal. The results show a weighting of $38 \%, 23.4 \%$ and $39.6 \%$ for creativity, intelligence and urban sustainability respectively. The contributions and implications for theory and practice, followed by indications for future research and the conclusions are also presented.
\end{abstract}

Key Words: creativity, intelligence, urban sustainability, composite index, performance, cities.

\section{Introduction}

Cities are increasingly seen as the main driver of regional and global economic development, irrespective of their population density or geographical context and cities' role in economic development has changed considerably, with them ceasing to be simply places of population density, business and employment (Haberstroh and Pinkwart 2018). However, some duality has persisted in the emphasis of local governments and central political decision-makers regarding the strategies adopted and the inherent investment, for example Silicon Valley, Bavaria Valley (Bavaria), Silicon Glen (Scotland), Silicon Saxony (Dresden, Hospers and Pen 2008), Barcelona, San Francisco, Glasgow (Amin and Thrift 2007), Rotterdam and Amsterdam (Romein and Trip 2009), whose strategies differ from each other. Given this scenario, the European Union, aiming for European cities characterised by competitiveness and territorial and social cohesion, defined strategies to be implemented at micro level - cities - by member countries so that inclusive, intelligent and sustainable growth can become a reality (Eurostat 2019).

In this context, interest has been aroused in the academic community regarding cities and the route they have chosen to grow in all their dimensions. Today's cities are multi-dimensional and pluralist places conciliating the historical past with the future, culture with economic factors, talents, technology and business with sustainability and with creativity (Power and Scott 2011, Ratten 2017), so that wealth creation can be demonstrated and supported by tri-partite pillars creativity, intelligence and urban sustainability - to allow long-term growth and sustained performance (Rodrigues and Franco 2018). Obviously, this path is an enormous challenge for political decision-makers and local governments, as these objectives imply multiple transformations (Bouton et al. 2013), going beyond the traditional models of economic growth and including both tangible and intangible factors (Romero-Padilla et al. 2016). This means that the strategies implemented and to be implemented in cities should be directed to the strategic governance of spaces and places (Audretsch 2003, Malecki 2007), towards people and not 
simply to organisational structures (Audretsch 2003).

For Rodrigues and Franco (2018), a paradigmatic change is found in the vision of the role and future of cities, stimulated by the phenomenon of globalization and it's meant that cities' economic and political importance grew quickly and that political decision-makers understood these help to solve their everyday problems of a social, economic and environmental nature. This vision is shared by the Networked Society City Index (Ericsson 2016) where the aim is for cities to become more inclusive, safe, resilient, creative, intelligent and sustainable, supported by the use of ICT and network connectivity, and by adopting a more sustainable consumption model - the circular economy.

However, this paradigmatic change in the role of today's cities in economic growth has given rise to a vast amount of literature on this topic (Florida 2005, Scott 2006, Mcgranahan and Wojan 2007, Landry 2012, Tranos and Gertner 2012, Cabrita et al. 2013, Ratiu 2013, Letaifa 2015, Girard et al. 2016, FPA 2017, Ortegel 2017, Rahbarianyazd and Doratli 2017, Florida 2019), directed towards creative, intelligent and sustainable cities, to the connection between culture, urban regeneration, collaboration processes and partnerships, and the economic and non-economic factors of multi-dimensional performance of cities today. This heterogeneity of theoretical and empirical studies has stimulated the development of indices to measure cities' performance regarding their creativity (Florida et al. 2007, Giffinger et al. 2007, Kakiuchi 2016, Montalto et al. 2019), intelligence (Picard et al. 2003, Carli et al. 2013, EY 2016, Angelidou 2017) and sustainability (Irungbam 2016, Trivellato 2016, European Commission 2019).

However, these indices have not yet filled the existing gaps in the literature on the measurement of cities' performance as a whole, noting a shortage of studies including the dimensions of creativity, intelligence and sustainability in a single index with the required scientificity. The importance of constructing a composite index was evidenced by Rodrigues and Franco (2018), who claimed that the performance of cities must be measured based on a holistic perspective and objective. In addition, the most studied topics have been global cities, incredible cities, city networks and city paradigms in social, ecological and cultural terms (Nijkamp and Kourtit 2013). In this area, there is a steady production of empirical studies addressing cities' performance (Malecki 2007) through indices showing a compilation of indicators in the various dimensions characterising cities (Borén and Young 2013, Flores and Teixeira 2017), with a great number of variables and for large samples (Çetindamar and Günsel 2012). Another gap identified concerns the relevance of including performance indicators that ally creativity and culture to sustainability, networks and their synergies for cities' sustainable and intelligent performance (Carta 2009, Tranos and Gertner 2012, Walker and Hills 2012, Cabrita et al. 2013, Echebarria et al. 2016, Bifulco et al. 2017, Cohen et al. 2017, Della Lucia et al. 2017, Ferraris et al. 2018). It should be noted that it is underlying in these gaps that creativity allows bridges to be created for the smart axis, as an adjective, as well as for sustainability, supported by the formation of networks, which allow synergies to be created between all city amenities (Ratten 2017). Another fundamental gap identified in the extensive literature concerns filling the existing gap between theory and practice (Lee et al. 2014), leading to Mora et al. (2017) calling for more studies designing holistic models of how current cities are built and about the scientific instruments that can help all actors involved in that construction (Priano and Guerra 2014, Huovila et al. 2017).

Aiming to fill these gaps, this study aims to present the scientific and robust weighting of the creativity, intelligence and urban sustainability dimensions in cities' holistic, integrated and overall performance. More precisely, the following specific objectives are defined: 1) to present an empirical performance measurement study, for sample and large dimension variables; 2) to treat these variables by multivariate statistical techniques, in order to construct a holistic composite index; and 3) with the answer to objectives 1 and 2, it is intended to bridge the gap between theory and practice. In short, this investigation aims to present the scientific and 
robust weighting of creativity, intelligence and urban sustainability dimensions in the cities' holistic, integrated and global performance. This objective implies the previous construction of Composite Indices for each of those dimensions. Thus, among the various contributions of this empirical study, the main one lies in presenting a Composite Index for the holistic performance of today's creative cities with the respective scientific weightings.

\section{Literature review}

\section{Dimensions of today's creative cities}

The new role attributed to today's cities concerning economic growth has caused a certain ambiguity around the concept itself and the dimensions included, which means that studies on cities should be holistic and integrated. The literature on this topic highlights creativity (Scott 2000, Florida 2005, Hospers and Pen 2008, Pratt 2008, Grant and Kronstal 2010, Landry 2012, Kong 2014, Kakiuchi 2016, Ratten 2017, Florida 2019), intelligence (Dodgson and Gann 2011, Nam and Pardo 2011, Letaifa 2015, Mardikyan et al. 2015, Bouk et al. 2017, Ratten 2017) and urban sustainability (Cavalcanti 1995, Camagni et al. 1998, Elkington 2004, Wheeler and Beatley 2014, Pozdniakova 2017) as inseparable dimensions of cities at the present time. These dimensions point us towards simultaneously creative, intelligent and sustainable cities, and these are defined as possessing a creative, diversified, open and tolerant climate, creative talents and relevant cultural dynamics (Florida 2005, Romein and Trip 2009, Grant and Kronstal 2010), provided by participative governance, the adoption of technology, recognition of the social, human, physical, cultural and natural capital in which social and environmental questions are included (Bibri and Krogstie 2017, Ratten 2017). It should be noted that this line of thinking assumes that urban sustainability in cities integrates social development, economic development, environmental management and urban governance, which refers to the management and investment decisions taken by municipal authorities in coordination with national authorities and institutions (Donegan and Lowe 2008, World Economic and Social Survey 2013). In addition, intelligence here is not only related to ICT and its various vectors, but to how urban creativity can be intelligently developed, and so that to emphasize social and human capital (Partridge 2004, Hoyman and Faricy 2009). In this context, what is understood by the intelligence dimension in the present research is that it can also be encompassed by creative and sustainable cities (Rodrigues and Franco 2019a). In this context, current cities' overall performance must be addressed in a tri-partite and holistically integrated way.

This holistic approach to today's cities aims to show that they must be provided with creative/ favourable environments to stimulate the attraction and interaction of talented people and the fulfilment of cultural synergies, in articulation with the co-creation of economic value and with a catalysing effect in promoting urban regeneration and thereby achieving urban sustainability (Furtado and Alves 2012). However, the advantages of intelligence must be indexed to those driving forces in order to make cities even more attractive and entrepreneurial (Caragliu et al. 2011). Furthermore, creativity in cities arises from the catalysing benefit of culture through restoration and regeneration of cultural heritage as a driver of the economy by encouraging synergies, networks and partnerships between all stakeholders in order to obtain economic return in the present and future (Girard et al. 2016); intelligence is shown by the support of value exchange cycles, the circular economy process, the participative and creative process and urban sustainability, by recognizing the importance of their tangible and intangible amenities as predictors of their quality of life and performance (Neirotti et al. 2014). In this sense, Fig. 1 shows the conceptual model of a current city, approached holistically and characterised by multiple dimensions and sub-dimensions. This model is complemented in the following section by indicators and proxies to measure the overall, integrated performance of today's cities. 


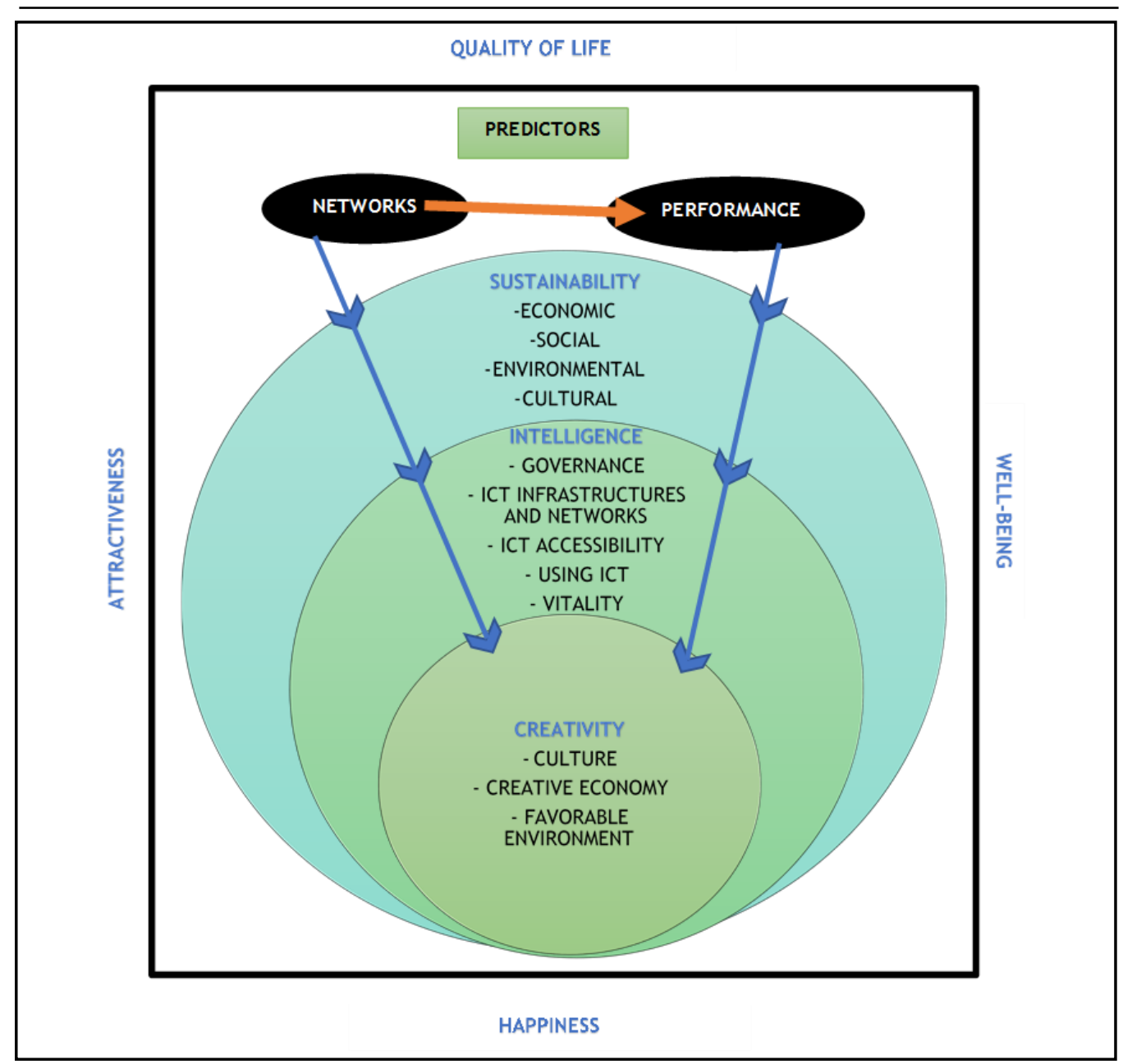

Fig. 1 - Multi-dimensional design model for currents cities

Source: Rodrigues and Franco (2018)

\section{Creative, intelligent and sustainable performance of creative cities}

Cities' global performance should be measured through a multi-dimensional and holistic approach (Ericsson 2016, Girard et al. 2016), due to cities' crucial role in the global economic development as places of connectivity (networks), creativity and innovation associated with social and economic progress, culture, diversity and the environment (European Commission 2011). In other words, cities' performance includes dimensions inherent to their tangible and intangible resources, as argued by Anthopoulos (2017), and it is the reflection of the strategies implemented with a view to giving cities creativity, intelligence and urban sustainability (Davoudi and Sturzaker 2017).

In this context, there is still a dispersion of indices and indicators to measure performance, due to the complexity of managing a city holistically (Albino et al. 2015), despite all of them aiming 
to improve citizens' quality of life (Shapiro 2006, ISO 2018). In other words, this performance is measured by a battery of indicators, which are understood as a methodological instrument, since the analysis of the used indicators allows political decision-makers to identify cities' opportunities/threats so that their global performance can improve continuously and sustainably (U4SSC 2017), irrespective of their size. Corroborating this argument, Borsekova et al. (2018) concluded that a city's size does not determine the implementation of strategies emphasizing creativity, intelligence and sustainability, since people are important in their integrated approach (Giffinger et al. 2007, Hollands 2008, Nam and Pardo 2011).

Recognizing that not all existing indices, indicators and proxies to measure cities' global performance have been explored, Table 1 compiles the most used of them by the academic community and by other public and private entities.

\section{Index of creativity, intelligence and urban sustainability}

Table 1

\begin{tabular}{|c|c|c|}
\hline Sub-dimension & General indicator & Source \\
\hline \multicolumn{3}{|r|}{ Creativity } \\
\hline \multirow{2}{*}{ Culture } & $\begin{array}{l}\text { Places of culture and } \\
\text { facilities }\end{array}$ & \multirow{2}{*}{$\begin{array}{l}\text { Giffinger et al. (2007), Durmaz et al. (2010), Hartley et al. } \\
\text { (2012), Lombardi et al. (2012), García Suárez and Pulido } \\
\text { Fernández (2015), Kakiuchi (2016), Bosch et al. (2017), } \\
\text { European Union (2017) }\end{array}$} \\
\hline & $\begin{array}{l}\text { Cultural participation } \\
\text { and attractiveness }\end{array}$ & \\
\hline \multirow{2}{*}{$\begin{array}{l}\text { Creative } \\
\text { economy }\end{array}$} & $\begin{array}{l}\text { Creativity and em- } \\
\text { ployment }\end{array}$ & \multirow{2}{*}{$\begin{array}{l}\text { Giffinger et al. (2007), Caragliu et al. (2011), Hartley et al. } \\
\text { (2012), Landry (2012), Lombardi et al. (2012), Panal and } \\
\text { Yáñez (2012), Joss et al. (2013), García Suárez and Pulido } \\
\text { Fernández (2015), Kakiuchi (2016), Bosch et al. (2017), } \\
\text { European Union (2017), Skavronska (2017) }\end{array}$} \\
\hline & $\begin{array}{l}\text { Intellectual property } \\
\text { and innovation }\end{array}$ & \\
\hline \multirow{4}{*}{$\begin{array}{l}\text { Favourable } \\
\text { environment }\end{array}$} & $\begin{array}{l}\text { Human capital and } \\
\text { education }\end{array}$ & \multirow{4}{*}{$\begin{array}{l}\text { Giffinger et al. (2007), Caragliu et al. (2011), Hartley et al. } \\
\text { (2012), Landry (2012), García Suárez and Pulido Femández } \\
\text { (2015), Dhingra and Chattopadhyay (2016), EPA (2016), } \\
\text { European Union (2017), Skavronska (2017) }\end{array}$} \\
\hline & $\begin{array}{l}\text { Openness, tolerance } \\
\text { and trust }\end{array}$ & \\
\hline & $\begin{array}{l}\text { Local and } \\
\text { international } \\
\text { connections }\end{array}$ & \\
\hline & Governance & \\
\hline \multicolumn{3}{|r|}{ Intelligence } \\
\hline \multirow{3}{*}{ Governance } & Implementation & Landry (2012), U4SSC (2017) \\
\hline & Strategy & Landry (2012), Madeira et al. (2016), Angelidou (2017), Bosch \\
\hline & Best practices & $\begin{array}{l}\text { Giffinger et al. (2007), Lombardi et al. (2012), García Suárez } \\
\text { and Pulido Fernández (2015), Angelidou (2017), Bloom } \\
\text { Consulting (2017), Garau et al. (2017) }\end{array}$ \\
\hline \multirow{5}{*}{$\begin{array}{l}\mathrm{ICT} \\
\text { infrastructure } \\
\text { and networks }\end{array}$} & Telecommunications & EY (2016), Ericsson (2016) \\
\hline & Transport & \multirow{4}{*}{ EY (2016) } \\
\hline & Energy & \\
\hline & Environment & \\
\hline & Sensors & \\
\hline
\end{tabular}


Margarida RODRIGUES, Mário FRANCO

\begin{tabular}{|c|c|c|}
\hline \multirow{2}{*}{ ICT accessibility } & Tariffs & Ericsson (2016) \\
\hline & Mobility & $\overline{E Y}(2016)$ \\
\hline \multirow{3}{*}{ Use of ICT } & of technology & Giffinger et al. (2007), Lombardi et al. (2012), Ericsson (2016) \\
\hline & Individual & Giffinger et al. (2007), Lombardi et al. (2012), Ericsson (2016) \\
\hline & Public & $\begin{array}{l}\text { Giffinger et al. (2007), Caragliu et al. (2011), Lombardi et al. } \\
\text { (2012), EY (2016), Ericsson (2016), Madeira et al. (2016), } \\
\text { Bloom Consulting (2017) }\end{array}$ \\
\hline Vitality & Individual and public & EY (2016) \\
\hline \multicolumn{3}{|r|}{ Sustainability } \\
\hline \multirow[t]{2}{*}{ Economic } & Competitiveness & $\begin{array}{l}\text { Giffinger et al. (2007), Caragliu et al. (2011), Lombardi et al. } \\
\text { (2012), Devol et al. (2015), Adnan et al. (2016), Arcadis (2016), } \\
\text { Bloom Consulting (2017), Bosch et al. (2017), EPA (2016), } \\
\text { Ericsson (2016), Trivellato (2016) }\end{array}$ \\
\hline & Economic activity & $\begin{array}{l}\text { Giffinger et al. (2007), Lombardi et al. (2012), Ericsson (2016), } \\
\text { Trivellato (2016), Angelidou (2017), Bloom Consulting (2017) }\end{array}$ \\
\hline \multirow{4}{*}{ Social } & Population & $\begin{array}{l}\text { Giffinger et al. (2007), Lombardi et al. (2012), EPA (2016), } \\
\text { Trivellato (2016), Bloom Consulting (2017), Bosch et al. (2017) }\end{array}$ \\
\hline & Education & $\begin{array}{l}\text { Giffinger et al. (2007), Lombardi et al. (2012), Arcadis (2016), } \\
\text { EPA (2016), Ericsson (2016), Trivellato (2016), Bloom Consult- } \\
\text { ing (2017), Bosch et al. (2017) }\end{array}$ \\
\hline & $\begin{array}{l}\text { Inclusion and cohe- } \\
\text { sion }\end{array}$ & Giffinger et al. (2007), Trivellato (2016), Bosch et al. (2017) \\
\hline & Social infrastructure & $\begin{array}{l}\text { Giffinger et al. (2007), Lombardi et al. (2012), Ericsson (2016), } \\
\text { Trivellato (2016), Bloom Consulting (2017), Bosch et al. (2017) }\end{array}$ \\
\hline \multirow{4}{*}{ Environmental } & Basic infrastructure & $\begin{array}{l}\text { Lombardi et al. (2012), Arcadis (2016), Ericsson (2016), Bosch } \\
\text { et al. (2017) }\end{array}$ \\
\hline & $\begin{array}{l}\text { Emission and pro- } \\
\text { duction of atmos- } \\
\text { pheric pollution }\end{array}$ & $\begin{array}{l}\text { Giffinger et al. (2007), Lombardi et al. (2012), Joss et al. } \\
\text { (2013), Ericsson (2016), Bloom Consulting (2017), Bosch et al. } \\
(2017)\end{array}$ \\
\hline & Circular economy & Ligorio (2017), Smol et al. (2017) \\
\hline & Urbanism & $\begin{array}{l}\text { Lombardi et al. (2012), Arcadis (2016), Dhingra and Chatto- } \\
\text { padhyay (2016), EPA (2016), Ericsson (2016), Bloom Consult- } \\
\text { ing (2017), Artmann et al. (2019) }\end{array}$ \\
\hline
\end{tabular}

\section{Methodology}

\section{Population}

The population observed is represented by the 308 towns and cities in Portugal (NUTS II), where those situated on the coast have a greater population density. The metropolitan areas of Lisbon and Porto have the greatest concentration of population. Table 2 presents the population distribution by region (NUTS III) and Fig. 2 represents the geographical spatiality of these 308 cities and towns.

\section{Data collection, indicators and proxies}

The steps in the construction of composite indicators were: theoretical framework (should be developed to provide a basis for the selection and combination of indicators) and data selection (based on the characteristics of a good indicator) (Nardo et al. 2005, OECD 2008). So, after the compilation of all indicators (variables) for the measurement of the holistic performance of cities/towns and, thus, validating the presented conceptual model, it was necessary to adapt them to the Portuguese context and to construct them from a database directed to cities, which 
is non-existent in Portugal. The numerical data for each variable was not collected randomly and it met the requirements of a good indicator (Chang et al. 2018).

Population distribution in Portugal for 2017

\begin{tabular}{|l|c|c|}
\hline \multicolumn{1}{|c|}{ NUTS II } & Number of towns/cities & Population (number) \\
\hline North & 86 & 3580390 \\
\hline Centre & 100 & 2237640 \\
\hline Lisbon Metropolitan Area & 18 & 2827514 \\
\hline Alentejo & 58 & 715019 \\
\hline Algarve & 16 & 440543 \\
\hline Autonomous Region of the Azores & 19 & 244573 \\
\hline Autonomous Region of Madeira & 11 & 254622 \\
\hline Total & $\mathbf{3 0 8}$ & $\mathbf{1 0 3 0 0 3 0 0}$ \\
\hline
\end{tabular}

Source: Pordata (2019)

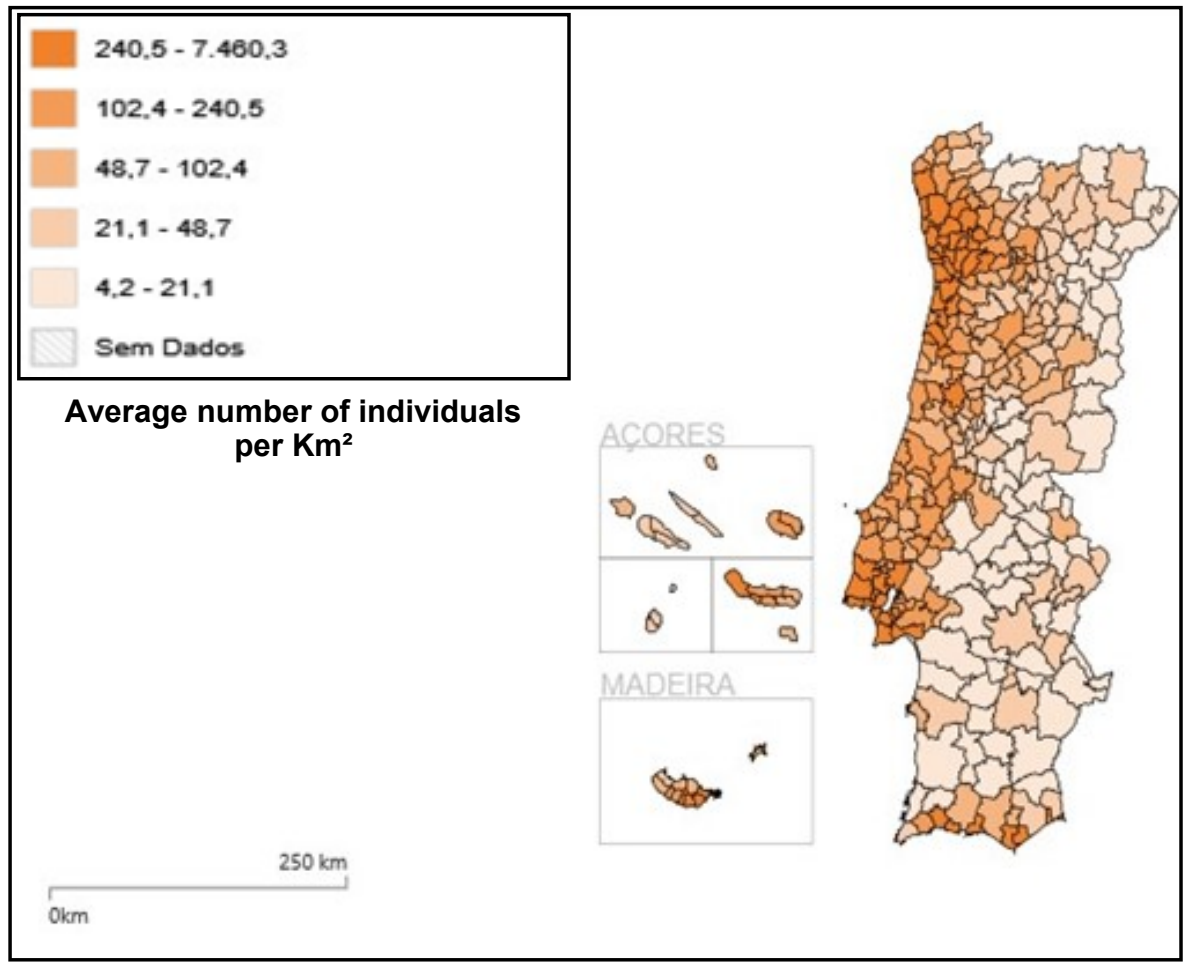

Fig. 2 - Population density in Portuguese local authorities Source: Pordata (2019) 
The collection of numerical data to produce the analysis is a crucial phase of this study, since the unavailability of data and resorting to various databases are unavoidable factors in the Portuguese context. Therefore, the database was formed by referring to various secondary sources - the National Statistics Institute (INE), PORDATA, and the official websites of various entities/institutions (e.g., Tripadvisor, Montalto et al. 2019) given the lack of a single database.

In these circumstances, the data-collection process began by obtaining the data available in the above-mentioned sources and by associating them with the dimension, sub-dimensions and indicators. This phase was extremely time-consuming and exhaustive so that the obtained database would be credible, reliable and suitable for the appropriate statistical treatment. Furthermore, the adaptation of the available data to the indicators and proxies most commonly used by academics and other entities implied an exhaustive search of theoretical and empirical work in various geographical contexts, so that this phase would be duly supported by scientific articles, minimizing the subjectivity inherent to the process. Therefore, the collected data present quality, reliability and comparability, as essential characteristics of a good indicator (Chang et al. 2018). Aware of the need to observe the requirements of a good indicator, it was also necessary to transform the absolute data obtained into relative data (proxy/resident population per 1000 city inhabitants), in order to allow the subsequent comparison between cities, irrespective of their size (Rodrigues and Franco 2019b).

The formed database is unique in Portugal, as official databases are not targeted at studies on cities, and so the result of this data-collection is a bonus for decision-makers in Portugal and it can be used for various purposes, besides those defined in this research.

Collecting data about the analysed population $(\mathrm{N}=308)$ was a lengthy process through the need to compile data, due to the non-existence of a single database with numerical information about the dimensions of creativity, intelligence and urban sustainability. Added to the dispersion of data was the insufficiency of data when the unit of analysis is represented by the town/city.

In these circumstances, the selection of indicators and respective proxies was governed above all by data availability, which did not prevent the selection considering the characteristics necessary for a good indicator, i.e., their clarity, simplicity, reproduction, scientificity, salience, credibility, legitimacy and comparability (Mega and Pedersen 1998, Atabek et al. 2005, Nardo et al. 2005). The listed indicators must have these characteristics, as the quality of a composite index depends on this (Saisana and Tarantola 2002, Stanickova and Melecký 2018), as well as the chosen research method. The appropriate definition of the research method, namely the multivariate statistical techniques, aims to overcome the dissimilarity of the units of measure and the periods of reference for the data by employing more than one indicator (Klúčik and Haluška 2008, OECD 2008). These authors also explain that the use of multiple indicators endow the obtained results with scientificity, relevance and meaning, as required by this typology of indices.

It was therefore indicated that measuring the global performance of the 308 Portuguese towns and cities should involve the aggregation and weighting methods defined by OECD (2008), i.e., the Exploratory Factor Analysis (EFA). However, a composite indicator is an aggregate of all dimensions, objectives, individual indicators and variables used (OECD 2008). Thus, in this study the composite index is used as an auxiliary means for calculating the weights of each dimension/sub-dimension (Rodrigues and Franco 2019b).

Given the high number of sub-dimensions (8) of used indicators (24 general and 47 specific indicators) and of proxies corresponding to the 154 variables to measure the creative, intelligent and sustainable performance of cities, detailed information on these is found in Appendix 1 (summary of data collection). 


\section{Stages of Data Analysis}

The statistical treatment of the data to assess the global performance of the 308 Portuguese towns and cities was performed by using the IBM SPSS software (version 25.0) and it covered three distinct stages, as also revealed by various authors (Pestana and Gageiro 2014, Danielis et al. 2018, Marôco 2018), for the studied dimensions: creativity, intelligence and urban sustainability. However, as the intention is to determine the scientific weighting of each of these dimensions in the cities' total performance, i.e., a Composite Index, the data analysis included two more stages (Kubrusly 2001, OECD 2008). The following paragraphs detail the methodological procedures associated with the set of five analysis stages.

The first step was to determine the validity of the 308 observations, and so the analysed observations represent around five times the studied variables, which ensures that no relevant information is lost. However, the heterogeneity of the units of measurement, the periods of reference and the possible omissions of data required data normalization, as any aggregation of data has to be preceded by this (Hair et al. 1995, Kubrusly 2001, Nardo et al. 2005, OECD 2008, Guimarães and Sarsfield Cabral 2010, Pestana and Gageiro 2014, Pituch and Stevens 2016, El Gibari et al. 2018, Marôco 2018).

In this study, Z-scores were chosen for data normalization. Z-scores converted the variables to a common scale with the mean of zero and the standard deviation of one (OECD 2008, Danielis et al. 2018, El Gibari et al. 2018, Marôco 2018). This means that the degree of dispersion was reduced to around zero for the mean and to one for the standard deviation (Castro-Higueras and de Aguilera-Moyano 2018). This analysis refers to the second stage, of descriptive analysis (mean, standard deviation, variation coefficient and minimum and maximum values), although the transformations arising from the above normalization mean are not presented in this study (OECD 2008, Marôco 2018).

The third stage concerns the calculation of weightings, considering that in building a composite index, the weights to attribute to each indicator have great significance for the total index and the obtained results (El Gibari et al. 2018). Supported by this crucial requirement, all the weightings presented in this study were obtained directly by applying the EFA and the intrinsic Principal Component Analysis (PCA), in order to present a robust Composite Index of quality. This scientific robustness and quality is obtained through the multivariate statistical techniques mentioned above, since they allow towns/cities to be taken as the unit of analysis (Al Sharmin 2011), the grouping of data presenting similar significance in the sample and the restriction of principal components to retain (Stevens 1986, Hair et al. 1995, Guimarães and Sarsfield Cabral 2010, Pestana and Gageiro 2014, Marôco 2018). This technique also allows the obtained weightings to represent the importance of the variables (154) measured by their maximum variance (Kubrusly 2001). The benefits of using EFA and PCA were stated by the OECD (2008), concluding that these can "summarise a set of individual indicators while preserving the maximum possible proportion of the total variation in the original data set", and that the "largest factor loadings are assigned to the individual indicators that have the largest variation across countries, a desirable property for cross-country comparisons, as individual indicators that are similar across countries are of little interest and cannot possibly explain differences in performance" (OECD 2008: 26). It is noted that in this study the unit of analysis is represented by the towns rather than the countries.

Finally, in the third stage, in order to check the acceptability of this technique, we applied the Kaiser-Meyer-Olkin (KMO, Kaiser 1974) sample suitability measure and the Bartlett sphericity test. In order to verify the internal consistency of the eight (sub)dimensions, it is usual to calculate the Cronbach's alpha, but this was not considered here as the "correlations do not necessarily represent the real influence of the individual indicators on the phenomenon expressed by the composite indicator" (OECD 2008: 27). 
The factor extraction requires variables in order to have a normal multivariate distribution, in which various more or less heuristic methods can be used to assess the data quality (Marôco 2018). Thus, the most commonly used method is the Kaiser-Meyer-Olkin sampling adequacy measure, as argued by Maroco (2014) and Pestana and Gageiro (2014). In the same sense, Nardo et al. (2005) and OECD (2008) explained that "multivariate normality of data is required for related significance tests. PCA and PFA have no distributional assumptions. Note, however, that a variant of factor analysis, maximum likelihood factor analysis, does assume multivariate normality. The smaller the sample size, the more important it is to screen data for normality. Moreover, as factor analysis is based on correlation (or sometimes covariance), both correlation and covariance will be attenuated when variables come from different underlying distributions (eg., a normal vs. a bimodal variable will correlate less than 1.0 even when both series are perfectly co-ordered)" (OECD 2008: 67).

After carrying out the first three stages for each dimension per se (creativity, intelligence and urban sustainability), we were ready for the next stages (4 and 5), since the weightings obtained for the 154 variables distributed over the analysed dimensions represent the starting point for these.

The fourth stage consisted of calculating the observed value for each town and its 8 subdimensions (culture, creative economy, favorable environment, governance, information and communication technology, economic, social and environmental sustainability) and then for the three dimensions (creativity, intelligence and urban sustainability), determined by the sum of the product between the value of each normalized variable by the weighting coefficient obtained for each of them in the previous stages (1,2 and 3). For the values observed by town, by sub-dimension and dimension, the descriptive analysis was performed. The data obtained at this stage were the variables to be analysed in the next stage, the calculation process being according to the one described by the OECD (2008).

Finally, the fifth stage concerned the application of EFA to the dimensions of creativity, intelligence and urban sustainability in order to obtain the total weight of each in the Composite Index of Portuguese towns/cities' total performance, with the first three stages being repeated.

\section{Results}

Following the procedures regarding to the third stage led to obtaining a great volume of statistical information, as all presented in Appendices 2 (creativity dimension), 3 (intelligence dimension) and 4 (urban sustainability dimension). It is important to mention that the values obtained in the KMO test for the sub-dimensions referring to each dimension (Kaiser 1974) show that data quality varies between reasonable, average and good, which means that EFA can be applied to them (Marôco 2018). However, in the creative economy sub-dimension of the creativity dimension, there was found to be a linear dependence between some of the studied variables, of which the Pearson correlation coefficient is 1 (Marôco 2018). Given the values obtained from the analysis of correlation between the variables of this sub-dimension, the variables of ATIC3, ATIC4, ICPIB4, ICPIB5, ICPIB6, TC2 and PP3 were withdrawn, in order to assess data quality through the KMO test.

In addition, the extracted communalities $\left(\mathrm{h}^{2}\right)$ respect the required minimum of $0.32 \%$ (Costello and Osborne 2005, Tabachnick and Fidell 2019) in all the analysed sub-dimensions (8). Similarly, the 154 analysed variables present loadings above the required minimum of 0.40 , and so the explained variances have significant values (Marôco 2018).

Finally, EFA and PCA retained a total of 51 factors for the dimensions of creativity (17), intelligence (12) and urban sustainability (22). Based on the values obtained for each factor, the next step (Kubrusly 2001) was to calculate the "weights from the matrix of factor loadings 
after rotation, given that the square of factor loadings represents the proportion of the total unit variance of the indicator which is explained by the factor" (OECD 2008: 90).

Based on these results, the conditions were right to calculate the weightings associated with each variable, obtained from the product between the normalized loadings raised to the square and the value of the explained variance for each factor, as shown in Tables 3, 4 and 5.

\section{Creativity dimension}

Table 3

\begin{tabular}{|c|c|c|c|c|c|c|c|}
\hline \multicolumn{8}{|c|}{ Weights - coefficients of variables ${ }^{5)}$} \\
\hline \multirow{2}{*}{ Variable } & \multicolumn{7}{|c|}{ Factor } \\
\hline & 1 & 2 & 3 & 4 & 5 & 6 & 7 \\
\hline \multicolumn{8}{|c|}{ Sub-dimension culture } \\
\hline$\overline{L I C 1}$ & & & & & 3.607 & & \\
\hline MA1 & & & & & & 4.118 & \\
\hline MA2 & & & & & & 3.351 & \\
\hline MA3 & & & & & & 2.162 & \\
\hline CIN1 & & & 4.789 & & & & \\
\hline CIN2 & & & 4.908 & & & & \\
\hline CE1 & & & & & & & 2.785 \\
\hline CE2 & & & & & 3.105 & & \\
\hline TEA1 & & 2.112 & & & & & \\
\hline RAL1 & 2.346 & & & & & & \\
\hline RAL2 & 5.651 & & & & & & \\
\hline RAL3 & 3.149 & & & & & & \\
\hline DORT1 & 5.341 & & & & & & \\
\hline DORT2 & 0.928 & & & & & & \\
\hline DORT3 & 5.420 & & & & & & \\
\hline VISM1 & & & & 5.251 & & & \\
\hline VISM 2 & & & & 5.095 & & & \\
\hline ATENC 1 & & 4.432 & & & & & \\
\hline ATENC2 & & 4.577 & & & & & \\
\hline DCE1 & & & & & & & 2.608 \\
\hline DCE2 & & 2.250 & & & & & \\
\hline OCC1 & & & & & 3.701 & & \\
\hline \multirow[t]{2}{*}{ DM1 } & & & & & & 1.674 & \\
\hline & $\begin{array}{l}\text { Hotels } \\
\text { and resta- } \\
\text { urants }\end{array}$ & $\begin{array}{l}\text { Thea } \\
\text { tres } \\
\text { and } \\
\text { simi- } \\
\text { lar }\end{array}$ & $\begin{array}{c}\text { Cine } \\
\text { ma }\end{array}$ & $\begin{array}{l}\text { Mu- } \\
\text { seum } \\
\text { visi- } \\
\text { tors }\end{array}$ & $\begin{array}{l}\text { Cultu- } \\
\text { ral } \\
\text { supply }\end{array}$ & $\begin{array}{c}\text { Art and } \\
\text { muse- } \\
\text { ums }\end{array}$ & $\begin{array}{c}\text { Cultural } \\
\text { premises }\end{array}$ \\
\hline
\end{tabular}
Table A)

5) Example of calculation for RAL1: $\left(0.276^{*} 0.085\right)^{\star} 100=2.346$ (values taken from Appendix 2, 


\section{Creativity dimension}

\begin{tabular}{|c|c|c|c|c|c|}
\hline \multicolumn{6}{|c|}{ Factor } \\
\hline & 1 & 2 & 3 & 4 & 5 \\
\hline \multicolumn{6}{|c|}{ Sub-dimension Creative Economy } \\
\hline EC1 & & 4.657 & & & \\
\hline ICPIB1 & & 6.450 & & & \\
\hline ICPIB2 & & & & 6.998 & \\
\hline ICPIB3 & & 5.794 & & & \\
\hline ICPIB7 & & 5.498 & & & \\
\hline ATIC1 & & 3.696 & & & \\
\hline ATIC2 & & & & 7.055 & \\
\hline ATIC5 & & & & & 6.728 \\
\hline ID1 & & & 4.587 & & \\
\hline ID2 & & & 6.437 & & \\
\hline ID3 & & & 4.599 & & \\
\hline TC1 & 5.639 & & & & \\
\hline TC3 & 3.811 & & & & \\
\hline TC4 & 6.165 & & & & \\
\hline PP1 & 5.511 & & & & \\
\hline PP2 & 5.794 & & & & \\
\hline & $\begin{array}{c}\text { R\&D } \\
\text { in higher } \\
\text { education } \\
\text { institu- } \\
\text { tions }\end{array}$ & $\begin{array}{c}\text { Creative } \\
\text { industries' } \\
\text { contribution to } \\
\text { GDP }\end{array}$ & $\begin{array}{l}\text { R\&D in } \\
\text { firms }\end{array}$ & $\begin{array}{l}\text { Proportion } \\
\text { of creative } \\
\text { industries }\end{array}$ & $\begin{array}{c}\text { Weight of } \\
\text { creative } \\
\text { industries }\end{array}$ \\
\hline & 1 & 2 & 3 & 4 & 5 \\
\hline \multicolumn{6}{|c|}{ Sub-dimension Favourable Environment } \\
\hline $\mathrm{CC} 1$ & 5.721 & & & & \\
\hline $\mathrm{CC} 2$ & 5.645 & & & & \\
\hline CC3 & 5.937 & & & & \\
\hline CC4 & 5.508 & & & & \\
\hline CC5 & 6.422 & & & & \\
\hline$\overline{\mathrm{CC} 6}$ & 6.503 & & & & \\
\hline $\mathrm{CC} 7$ & 4.209 & & & & \\
\hline $\mathrm{CC} 8$ & 1.946 & & & & \\
\hline PR1 & 3.427 & & & & \\
\hline TOL1 & & & & 4.930 & \\
\hline TOL2 & & 5.349 & & & \\
\hline TOL3 & & 4.006 & & & \\
\hline TOL4 & & & & 4.506 & \\
\hline LI1 & & & 3.311 & & \\
\hline $\mathrm{LI} 2$ & & & & & 2.220 \\
\hline
\end{tabular}


Creativity dimension

\begin{tabular}{|c|c|c|c|c|c|c|c|}
\hline \multicolumn{8}{|c|}{ Weights - coefficients of variables ${ }^{5)}$} \\
\hline \multirow{2}{*}{ Variable } & \multicolumn{7}{|c|}{ Factor } \\
\hline & 1 & 2 & 3 & 4 & 5 & 6 & 7 \\
\hline$\overline{\mathrm{LL} 1}$ & & & & & & & 5.155 \\
\hline FE1 & & & & & & & \\
\hline FE2 & & & & & & & \\
\hline \multirow[t]{2}{*}{ FE3 } & & & & & & & \\
\hline & $\begin{array}{l}\text { Higher } \\
\text { education }\end{array}$ & & ion & $\begin{array}{l}\overline{\operatorname{Red}} \\
\text { of } b\end{array}$ & $\begin{array}{l}\text { ment } \\
\text { is and } \\
\text { ts }\end{array}$ & Foreigners & Transport \\
\hline
\end{tabular}

Intelligence Dimension

Table 4

\begin{tabular}{|c|c|c|c|c|c|c|c|c|}
\hline \multicolumn{9}{|c|}{ Weights - coefficients of variables } \\
\hline \multirow[b]{2}{*}{ Variable } & \multicolumn{8}{|c|}{ Factor } \\
\hline & 1 & 2 & 3 & 4 & 5 & 6 & 7 & 8 \\
\hline \multicolumn{9}{|c|}{ Sub-dimension governance } \\
\hline EGOV1 & & & & 0.81 & & & & \\
\hline EGOV2 & & & & 5.15 & & & & \\
\hline EGOV3 & & & & & & & 1.54 & \\
\hline FIN1 & & & 6.4 & & & & & \\
\hline FIN2 & & & & 3.14 & & & & \\
\hline FIN3 & & & 6.4 & & & & & \\
\hline RED1 & & & & & & 3.29 & & \\
\hline RED2 & & & & & & 3.94 & & \\
\hline PEL1 & 6.08 & & & & & & & \\
\hline PEL2 & 6.31 & & & & & & & \\
\hline PEL3 & 3.66 & & & & & & & \\
\hline PEL4 & 5.91 & & & & & & & \\
\hline VIND1 & & 4.58 & & & & & & \\
\hline VIND2 & & & & 1.42 & & & & \\
\hline VIND3 & & & & & 3.36 & & & \\
\hline VIND4 & & 4.93 & & & & & & \\
\hline VIND5 & & 4.37 & & & & & & \\
\hline VPUB1 & & & & & & & 5.45 & \\
\hline \multirow[t]{2}{*}{ VPUB2 } & & & & 0.81 & & & & 5.04 \\
\hline & $\begin{array}{c}\text { Elec- } \\
\text { tion } \\
\text { turn- } \\
\text { out }\end{array}$ & $\begin{array}{l}\text { Popu- } \\
\text { lation } \\
\text { vitality }\end{array}$ & $\begin{array}{l}\text { Local } \\
\text { pub- } \\
\text { lic } \\
\text { debt }\end{array}$ & $\begin{array}{c}\text { E- } \\
\text { govern- } \\
\text { ment } \\
\text { vs. } \\
\text { Density } \\
\text { and } \\
\text { Income }\end{array}$ & Access & $\begin{array}{c}\text { Muni- } \\
\text { cipal } \\
\text { provi- } \\
\text { sion }\end{array}$ & $\begin{array}{c}\text { Urban } \\
\text { net- } \\
\text { works }\end{array}$ & $\begin{array}{l}\text { Tou- } \\
\text { rism }\end{array}$ \\
\hline
\end{tabular}


Intelligence Dimension

\begin{tabular}{|c|c|c|c|c|}
\hline \multicolumn{5}{|c|}{ Sub-dimension ICT } \\
\hline & 1 & 2 & 3 & 4 \\
\hline TEL1 & 10.96 & & & \\
\hline TEL2 & 11.07 & & & \\
\hline AMB1 & & 10.11 & & \\
\hline AMB2 & & 9.12 & & \\
\hline AMB3 & & & 8.83 & \\
\hline AMB4 & & & & 10.77 \\
\hline ACES1 & & & 5.47 & \\
\hline ACES2 & 8.75 & & & \\
\hline PUB1 & & 8.94 & & \\
\hline IND1 & 4.24 & & & \\
\hline & Communications and internet & Network infrastructure & Energy and mail & Waste \\
\hline
\end{tabular}

Urban Sustainability Dimension

Table 5

\begin{tabular}{|c|c|c|c|c|c|c|c|}
\hline \multicolumn{8}{|c|}{ Weights - coefficients of variables } \\
\hline \multirow{2}{*}{ Variable } & \multicolumn{7}{|c|}{ Factor } \\
\hline & 1 & 2 & 3 & 4 & 5 & 6 & 7 \\
\hline \multicolumn{8}{|c|}{ Sub-dimension Economic sustainability } \\
\hline CREC1 & & 2.75 & & & & & \\
\hline CREC2 & 0.99 & & & & & & \\
\hline CREC3 & 4.12 & & & & & & \\
\hline CREC4 & & 1.05 & & & & & \\
\hline CREC5 & & & & 1.28 & & & \\
\hline NEG1 & & 4.58 & & & & & \\
\hline NEG2 & & 3.75 & & & & & \\
\hline NEG3 & & & & & 3.02 & & \\
\hline NEG4 & & & 3.58 & & & & \\
\hline NEG5 & & 3.46 & & & & & \\
\hline NEG6 & 3.59 & & & & & & \\
\hline NEG7 & 4.71 & & & & & & \\
\hline NEG8 & 4.35 & & & & & & \\
\hline NEG9 & & & 1.22 & & & & \\
\hline NEG10 & & & & 3.39 & & & \\
\hline EMP1 & & & & & & 3.79 & \\
\hline EMP2 & & & & 2.64 & & & \\
\hline EMP3 & & & 3.09 & & & & \\
\hline EMP4 & & & 4.37 & & & & \\
\hline EMP5 & & & & & 3.66 & & \\
\hline EMP6 & & & & & & & 4.85 \\
\hline \multirow[t]{2}{*}{ Total } & 17.76 & 15.59 & 12.26 & 7.31 & 6.68 & 3.79 & 4.85 \\
\hline & $\begin{array}{c}\text { Eco- } \\
\text { nomic } \\
\text { activity }\end{array}$ & $\begin{array}{c}\text { Growth and } \\
\text { employ- } \\
\text { ment }\end{array}$ & $\begin{array}{l}\text { Entrepre- } \\
\text { neurship }\end{array}$ & $\begin{array}{c}\text { Unem- } \\
\text { ployment }\end{array}$ & $\begin{array}{l}\text { Density } \\
\text { of baanks } \\
\text { and firms }\end{array}$ & $\begin{array}{l}\text { New } \\
\text { firms }\end{array}$ & $\begin{array}{l}\text { Public- } \\
\text { private } \\
\text { partner- } \\
\text { ships }\end{array}$ \\
\hline
\end{tabular}


Urban Sustainability Dimension

\begin{tabular}{|c|c|c|c|c|c|c|c|c|}
\hline & 1 & 2 & 3 & 4 & 5 & 6 & 7 & 8 \\
\hline \multicolumn{9}{|c|}{ Sub-dimension Social sustainability } \\
\hline AD1 & 4.77 & & & & & & & \\
\hline AD2 & 4.52 & & & & & & & \\
\hline AD3 & 2.16 & & & & & & & \\
\hline AD4 & 4.67 & & & & & & & \\
\hline AD5 & 3.00 & & & & & & & \\
\hline AD6 & & & & & & & & 2.41 \\
\hline AD7 & 1.97 & & & & & & & \\
\hline $\mathrm{ICH} 1$ & & & & & 4.27 & & & 0.00 \\
\hline $\mathrm{ICH} 2$ & & & & & & & & 3.32 \\
\hline $\mathrm{ICH} 3$ & & & & & 4.12 & & & \\
\hline ICOM1 & & & 4.55 & & 0.00 & & & \\
\hline ICOM2 & 3.16 & & & & & & & \\
\hline ICOM3 & 3.08 & & & & & & & \\
\hline ICOM4 & 3.16 & & & & & & & \\
\hline ICOM5 & 3.75 & & & & & & & \\
\hline PD1 & & & & & & & 3.37 & \\
\hline PD2 & & & & & & 1.74 & & \\
\hline PD3 & & & & 4.61 & & & & \\
\hline DSA1 & & 3.83 & & & & & & \\
\hline DSA2 & 1.34 & & & & & & & \\
\hline DSA3 & & & & & & & 1.59 & \\
\hline DSA4 & & 3.92 & & & & & & \\
\hline DSA5 & & & & 4.10 & & & & \\
\hline DSE1 & & & & & & 3.76 & & \\
\hline DSE2 & & & 4.11 & & & & & \\
\hline \multirow[t]{2}{*}{ Total } & 35.58 & 7.75 & 8.66 & 8.71 & 8.39 & 5.50 & 4.96 & 5.73 \\
\hline & $\begin{array}{c}\text { Demo- } \\
\text { graphy } \\
\text { and edu- } \\
\text { cation }\end{array}$ & Health & Other & $\begin{array}{c}\text { Social } \\
\text { projects }\end{array}$ & $\begin{array}{c}\text { Poverty } \\
\text { and } \\
\text { criminality }\end{array}$ & $\begin{array}{l}\text { Urban } \\
\text { renewal } \\
\text { (a) }\end{array}$ & $\begin{array}{l}\text { Other } \\
\text { bene- } \\
\text { fits }\end{array}$ & (a) \\
\hline
\end{tabular}


Sustainability Dimension

\begin{tabular}{|c|c|c|c|c|c|c|c|}
\hline \multicolumn{8}{|c|}{ Weights - coefficients of variables } \\
\hline \multirow{2}{*}{ Variables } & \multicolumn{7}{|c|}{ Factor } \\
\hline & 1 & 2 & 3 & 4 & 5 & 6 & 7 \\
\hline \multicolumn{8}{|c|}{ Sub-dimension Environmental sustainability } \\
\hline EGA1 & & 7.11 & & & & & \\
\hline EGA2 & & 7.42 & & & & & \\
\hline EGA3 & 5.21 & & & & & & \\
\hline EPAT1 & 5.34 & & & & & & \\
\hline EPAT2 & 5.93 & & & & & & \\
\hline RR1 & 3.67 & & & & & & \\
\hline RR2 & 3.53 & & & & & & \\
\hline RR3 & & & 6.39 & & & & \\
\hline RR4 & & & & & & 7.73 & \\
\hline RR5 & 3.86 & & & & & & \\
\hline RR6 & 3.38 & & & & & & \\
\hline TER1 & & & & 5.89 & & & \\
\hline TER2 & & & & 5.36 & & & \\
\hline TER3 & & & & & & & 4.43 \\
\hline TER4 & & & & & 5.00 & & \\
\hline \multirow[t]{2}{*}{ TER5 } & & & & & 5.44 & & \\
\hline & \multicolumn{3}{|c|}{$\begin{array}{l}\text { Management of waste } \\
\text { and basic } \\
\text { consumption (a) }\end{array}$} & \multicolumn{2}{|c|}{$\begin{array}{l}\text { Preservation and } \\
\text { protection of the } \\
\text { environment (b) }\end{array}$} & (a) & (b) \\
\hline
\end{tabular}

The respective weightings allowed the calculation of the value observed for each town, which was obtained by summing the product of each normalized variable ( $Z$ scores), as obtained with the IBM SPSS software by the weighting (the fourth stage). These calculations were made for all the analysed dimensions (3) and sub-dimensions (8). For example, the numerical value of the creativity dimension for a town was obtained as follows:

$$
\begin{aligned}
&\left.\sum \text { (Zscore } i * \text { weighting } i\right)+\cdots(Z \text { score } i * \text { weighting } i) \\
&=\text { value observed for a town in the culture sub-dimension (1.61926) Formula } 1
\end{aligned}
$$

( $\mathrm{i}=$ LIC1 to DM1, where $\mathrm{i}=23$ variables; $\mathrm{Z}$ scores obtained through SPSS)

However, in order to calculate the final weighting of each of the 3 analysed dimensions, it was necessary to determine the weight of each sub-dimension analysed in the respective dimension, and so the EFA was applied.

It was then necessary to calculate the numerical value per town for each dimension, resulting from the sum of the product between the value observed per town for each sub-dimension in the dimension. As an example for the creativity dimension, we have the following formula:

Culture $\left(1.6191^{1} * 0.222^{2}\right)+$ Creative Economy $\left(4.9873^{3} * 0.38\right)+$ Favourable Environment $\left(3.1714^{4} * 0.396\right)$ = Creativity (3.5158) Formula 2

1) Values obtained from formula 1

2) Appendix 5

3) Values obtained from formula 1

4) Values obtained from formula 1 
Finally, following the descriptive analysis (Table 6), the values obtained from formula 2 for the 308 Portuguese towns and cities represented the numerical data to enter in SPSS for the creativity (variable 1), intelligence (variable 2) and urban sustainability (variable 3 ) dimensions in order to apply the EFA (Table 7), aiming to obtain the composite weighting of each dimension in the total performance of Portuguese towns (the fifth stage).

Descriptive statistics of the population

Table 6

\begin{tabular}{|l|c|r|r|r|r|}
\hline \multicolumn{1}{|c|}{ Dimensions } & N & Mean & $\begin{array}{l}\text { Standard } \\
\text { Deviation }\end{array}$ & Minimum & Maximum \\
\hline Creativity & 308 & 0.000 & 0.383 & -0.3077 & 3.5158 \\
\hline Intelligence & 308 & 0.000 & 0.261 & -0.6105 & 0.9299 \\
\hline Urban Sustainability & 308 & 0.000 & 0.230 & -0.4519 & 1.5015 \\
\hline
\end{tabular}

Table 7

Exploratory Factor Analysis for the dimensions of creativity, intelligence and urban sustainability

\begin{tabular}{|l|c|c|c|}
\hline \multicolumn{1}{|c|}{ Dimensions } & \multirow{2}{*}{$\mathbf{h}^{\mathbf{2}}$} & $\begin{array}{c}\text { Factor } \\
\text { Total } \\
\text { Performance }\end{array}$ & \multirow{2}{*}{ Weights $^{6)}$} \\
\cline { 2 - 3 } & 0.692 & $\mathbf{1}$ & 0.382 \\
\hline Creativity & 0.426 & 0.652 & 0.234 \\
\hline Intelligence & 0.702 & 0.838 & 0.396 \\
\hline Urban Sustainability & & 1.82 & \\
\hline Eigenvalue & & 60.65 & \\
\hline \% explained variance & & 60.65 & \\
\hline Total explained variance & & & \\
\hline Varimax Rotation; $\mathrm{N}=308 ;$ & &
\end{tabular}

Varimax Rotation; $\mathrm{N}=308$; KMO = 0.613; Bartlett

Sphericity Test:=162.366; gl = 3; $p<0.000$;

\section{Discussion}

The analysis results led to obtaining the scientific weighting of each dimension forming the Composite Index for the towns' total performance. So, in the Portuguese context, the intelligence dimension has the least significant weighting $(0.234)$, followed by the creativity dimension (0.380) and the urban sustainability dimension (0.396).

The global reading of these results indicates that political decision-makers and local governments have made relevant efforts to reflect the importance of these three dimensions in their strategies and guidelines, particularly at town level. These efforts represent a constant challenge given the transformations this implies in the various urban spaces, infrastructure, institutions and the implementation and monitoring processes. It is noted that this transformative scenario was mentioned by Bouton et al. (2013), due to economic growth also being stimulated by intangible and tangible amenities (Romero-Padilla et al. 2016). Furthermore, this paradigmatic alteration in the model of economic growth in urban areas led to people and spaces involved in the urban environment being revealed as crucial for cities' urban growth, with positive effects on their total performance (Audretsch 2003, Malecki 2007). In addition, for the Portuguese towns, it was confirmed that there has been a concentration on the endogenous cultural factors associated with the revitalization of places, aiming to develop the

6) Example of calculation for creativity: $0.832^{\wedge} 2 / 1.821628=0.380$ 
cultural activities and to also provide the premises for new businesses linked to culture and creativity. This involvement has been mentioned by several authors (Florida 2005, Cabrita et al. 2013, Ortegel 2017, Florida 2019).

The following paragraphs analyse the dimensions of creativity, intelligence and urban sustainability individually, as the weightings obtained for each require this.

The creativity dimension has a weighting of 0.380 in the total performance of Portuguese towns, in which culture has an impact of 0.22 , the creative economy 0.38 and the favourable environment 0.40 . This means that local governments in the 308 analysed towns and cities have directed their policies towards providing regenerated or even new cultural spaces, pluralist, tolerant and open urban environments, which in turn are attractive amenities for the so -called creative class (Florida 2005, Florida et al. 2007, Mcgranahan and Wojan 2007, Hoyman and Faricy 2009, Lawton et al. 2010, Florida 2019) and the implicit cultural and creative industries (Pratt 2008). This type of city provision was mentioned by Florida (2005), Grant and Kronstal (2010) and Romein and Trip (2009), who highlighted the importance of cities generating a favourable environment and a creative economy associated with the dynamics produced by culture and people's creativity as a lever to direct cities to creativity, intelligence and urban sustainability. Moreover, the factors obtained through EFA and the respective weightings of the variables included in them clearly show the positive impacts of creativity on performance in the 308 Portuguese towns and cities, for example, in the significance of the weightings of creative and cultural industries in the sub-dimension of the creative economy (Table 3), which means this is already happening in Portugal and it is generating economic value. The wealth produced by these industries was shown by Furtado and Alves (2012). These authors also argued that the economic results of cultural and creative industries allow them to contribute to cities' urban sustainability.

Although the intelligence dimension of Portuguese towns still requires action to improve infrastructure and accessibility, urban networks (belonging to inter and intra networks) in those towns are a positive aspect, as a reflection of adopting open, participative governance aiming to improve urban performance. Urban networks as predictors of improved city performance were emphasized by Cohen et al. (2016), Echebarria et al. (2016), Ferraris et al. (2018), in which creativity stimulates the creation of urban networks as a consequence of the adopted governance typology, as well as those networks increasing synergies between all urban agents, with an economic return in the present and future (Girard et al. 2016). Nevertheless, the implementation of ICT in Portuguese towns may fall short of expectations, despite the significant progress being made in terms of e-government. ICT's articulation with cities' governance is fundamental for their improved intelligent performance and for the benefits to be duly enjoyed (Neirotti et al. 2014). In this dimension, it is essential to mention that the obtained statistical results were influenced by the lack of data at the Portuguese town level, and so these could be overestimated.

The urban sustainability dimension is visible in the 308 Portuguese towns in a tri-partite way. Economic sustainability (weighting of 0.386 ) has been strengthened, for example, by entrepreneurship, which has created new business supported by public-private partnerships, such as living labs, which has contributed to less urban unemployment. Living labs, understood as open networks and collaborative partnerships, have been indicated as a means to extend connectivity inside and outside towns (Girard et al. 2016, Ericsson 2016), allowing the development and implementation of intangible projects with social, environmental and cultural effects, besides the projects with sustainable economic synergies (European Comission 2011, Anthopoulos 2017). Standing out in social sustainability (weighting of 0.245 ) represents the development of projects promoting cohesion and social inclusion and actions to improve the social infrastructure in Portuguese towns, for example, projects promoted by the healthy town 
network and others. This type of social projects and policies aiming for improved infrastructure is necessary to achieve urban sustainability (Giffinger et al. 2007, Arcadis 2016, Trivellato 2016, Bosch et al. 2017). Finally, environmental sustainability (weighting of 0.369), locally in Portugal, has emphasized waste management and actions to preserve and protect natural resources and the environment in general. However, the circular economy model proposed by the European Union is a scenario in need of additional strategies and policies, since it is at an embryonic stage in Portuguese towns. It is clearly necessary for towns to go down this route and thereby to improve their environmental performance even more. The importance of this model for the cities' improved sustainable performance was explained by Ligorio (2017) and by Smol et al. (2017), despite the suggestion that the circular economy should be interlinked with ICT and open governance (intelligence, Neirotti et al. 2014, Girard et al. 2016). Neirotti et al. (2014) also argue that cities with urban sustainability predict their performance positively and raise their residents' quality of life, and, in the case of Portugal, this dimension's weighting is very close to 0.40 .

Summarizing, the results obtained show that cities' performance can be measured in a multidimensional and holistic way, without losing relevant information and with scientific quality and robustness. Fig. 3 shows the results obtained for the 308 towns and cities in Portugal.

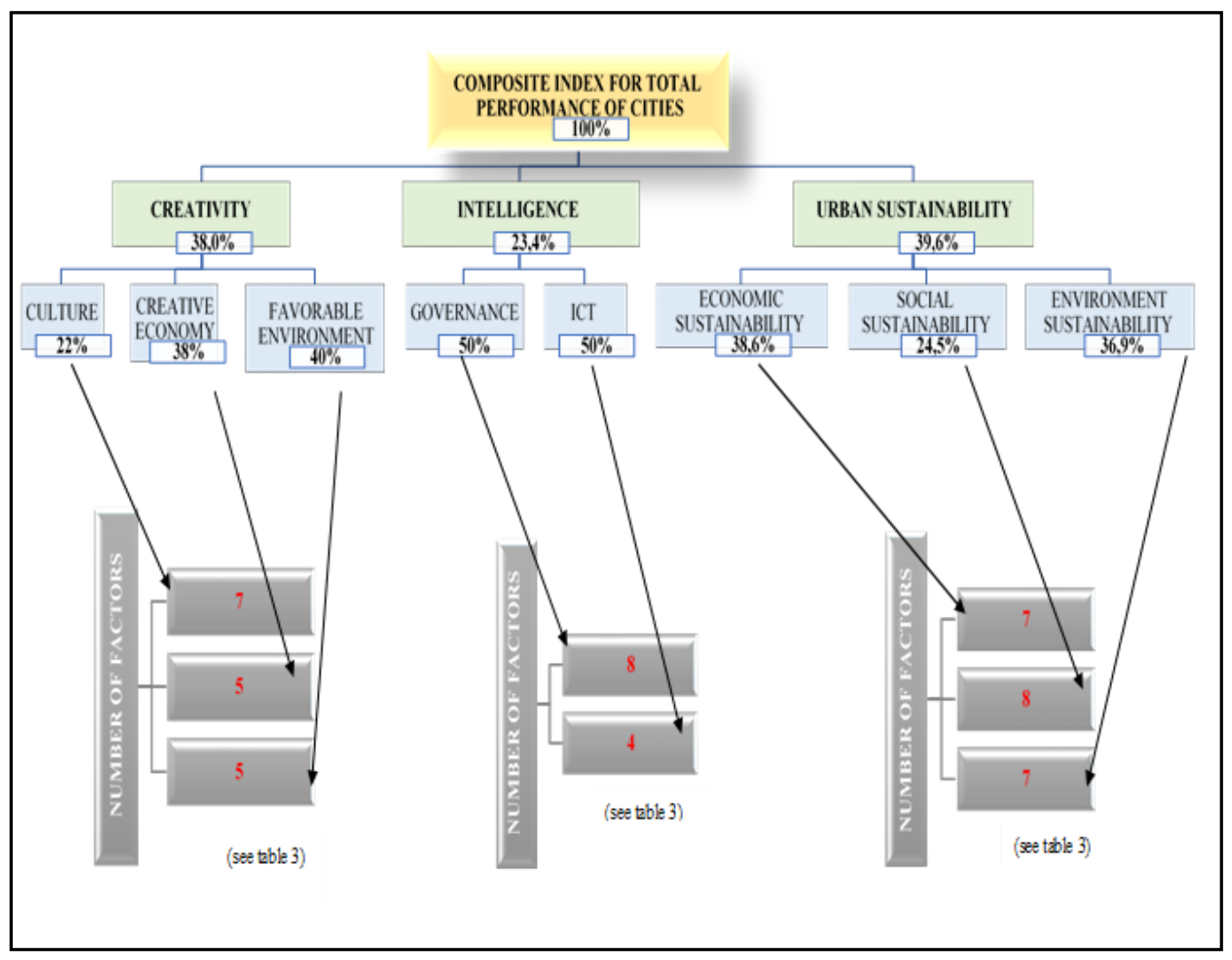

Fig. 3 - Composite index for the total performance of cities 
Portuguese towns and cities are moving according to the European Union directives towards achieving intelligent, inclusive and sustainable growth (Eurostat 2019), associated with creativity, culture and urban networks, with the last-named being understood as a new intangible factor of the current model of cities' economic growth and a predictor of improved total performance.

The contributions arising from the results obtained in this empirical study have relevant implications for theory and practice, allowing the existing gap between both to be filled (Lee et al. 2014), and this represents the study's general contribution.

The presentation of a theoretical and holistic framework, importance of which was already defended by Mora et al. (2017), is the first contribution of this study with implications for theory. The framework shows that today's towns aim to be simultaneously creative, intelligence and sustainable, and to grow economically in the short and long term in order to provide their residents with quality of life, well-being and happiness, besides improving their total performance predicted by inter and intra networks formed in urban spaces where the intangible effects give a financial return today and in the future.

The second contribution, also with implications for theory, lies in the compilation of indicators from various indices in a single index. This index includes indicators for the dimensions of creativity, intelligence and sustainability, divided in 8 sub-dimensions. Concerning the theoretical implications, a Composite Indicator with 24 general indicators and 47 specific indicators was developed, filling the gap regarding a single index to measure the total performance in all its inseparable dimensions (Malecki 2007, Borén and Young 2013), added to which is the volume of the used variables (Çetindamar and Günsel 2012).

Filling the theoretical gaps was followed by the empirical operationalization of the Composite Index. Consequently, the third contribution lies in the application of that index in the Portuguese context, with robustness and scientific quality being confirmed through the application of EFA (OECD 2008), in order for this to be a methodological instrument to be adopted by cities and/or countries to assess and monitor their total performance. It is highlighted that Composite Indices are an instrument increasingly valued by the political decision-makers and important in discussing economic growth, this being an implication for practice.

Overall, the main contribution of this study lies in the Composite Index for cities' total performance, with the statistical treatment allowing the scientific calculation of the weightings of each studied dimension for the cities' holistic performance.

Like any study, this one is not without limitations. One is the subjectivity presented in selecting the used indices/indicators, which were affected by the limited availability of data about towns and the fact of the choice also having to consider the characteristics of a good indicator. Also, the unavailability of data when the unit of analysis is the town, whatever its population density, is another limitation.

Given the multiplicity of theoretical concepts and implications for theory and practice, measuring cities' total performance does not end with this study, but it continues to be a fertile area for future research. The extensive data treatment carried out allows the elaboration of a ranking of Portuguese towns and cities by size and their total performance, directing future research to the analysis of clusters of Portuguese towns. Another future topic would be the application of other multivariate statistical techniques, for example, the Data Envelopment Analysis (DEA), which allows multiple entries and exits and it could establish a model of multifactor measurement of performance and frontiers in order to measure efficiency. A final 
suggestion is to apply the Composite Index in other geographical contexts, leading to comparative studies to determine the factors of cities' success and failure. Another study could take countries as the unit of analysis.

\section{Conclusions}

Creative cities in this century included in the so-called European Cities must ally the creativity dimension to those of intelligence and urban sustainability, as their growth is supported by the holistic, determinant pillars of their total performance. In this context, it was demonstrated that this can be scientifically measured through a Composite Index with the respective weightings, which allows its generalized application in any geographical context and unit of analysis. This generalization transforms this index into a scientific instrument for political decision-makers and town planners. It was also proven that when understood and managed as strategic places, cities are able to respond to the major challenge of being the drivers of a country's economic growth. This means that cities that increase their growth according to the premises inherent to creativity, intelligence and urban sustainability, as a whole and without neglecting the importance of urban networks, will show an improved total performance.

\section{Acknowledgements}

The authors thank the anonymous reviewers for their very helpful comments that contributed to the development of this paper. The authors gratefully acknowledge financial support from the National Funds of the FCT - Portuguese Foundation for Science and Technology within the project «UID/ECO/04007/2019». 
Appendix 1

Index of creativity, intelligence and urban sustainability for cities in Portugal

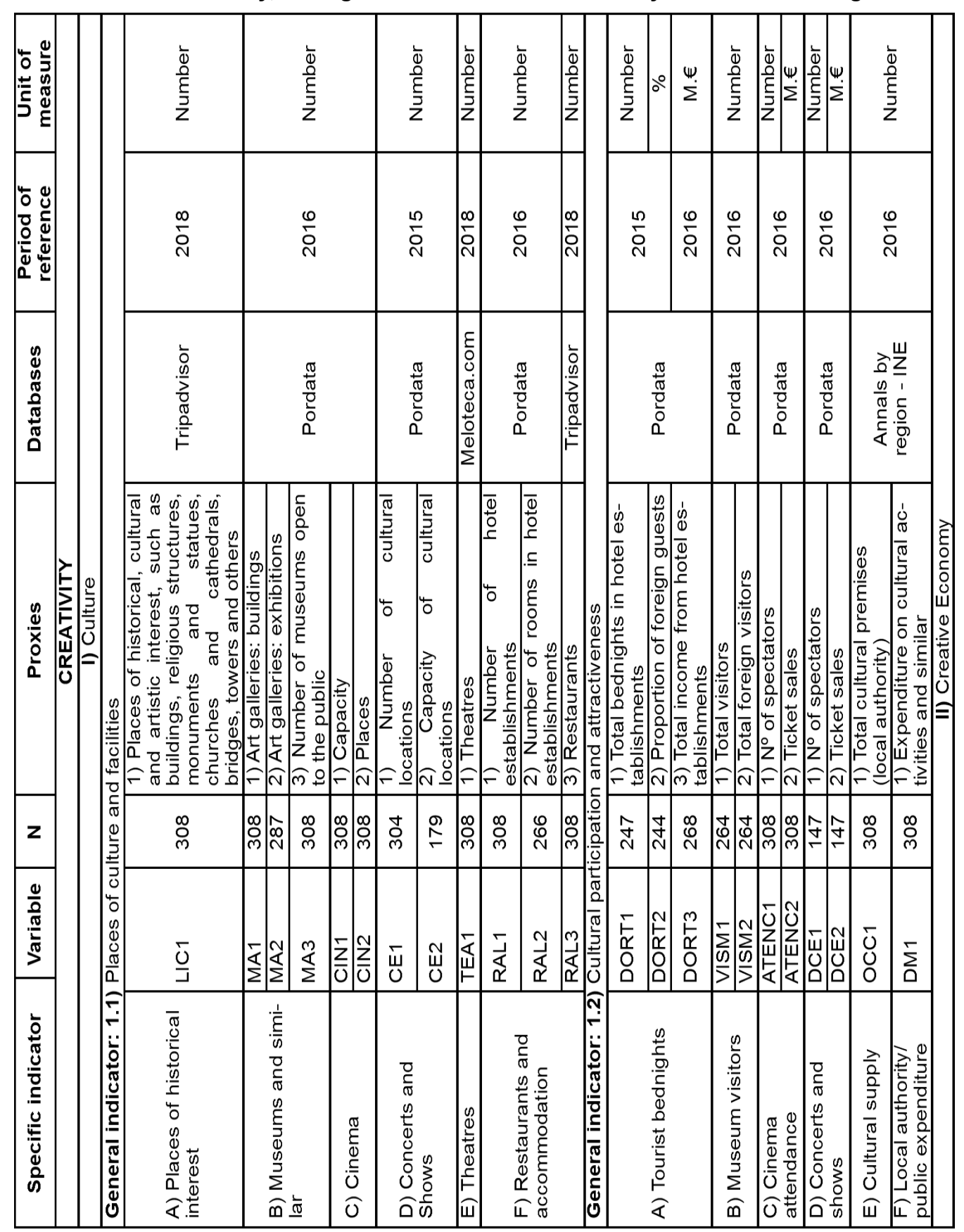




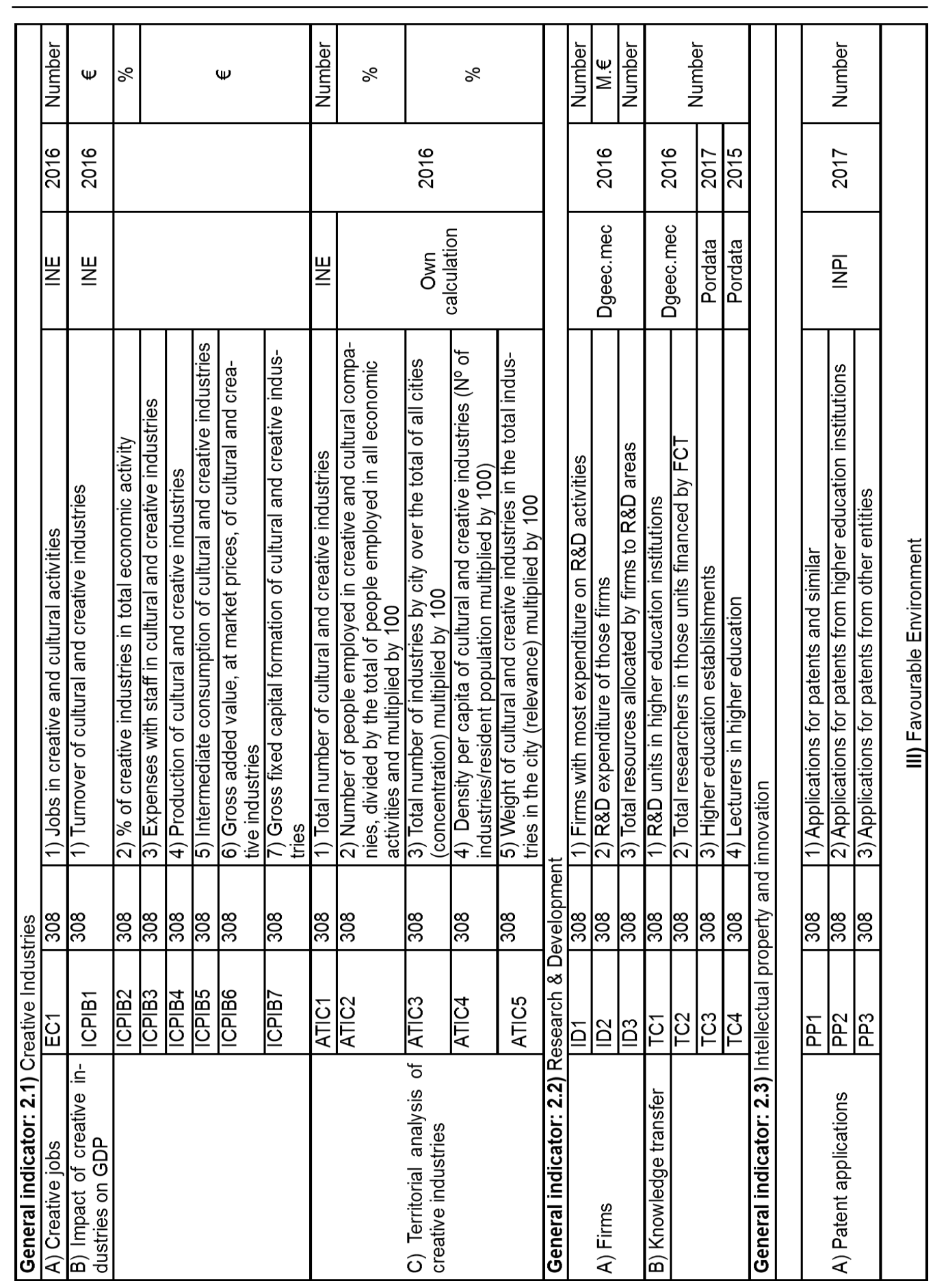


Margarida RODRIGUES, Mário FRANCO

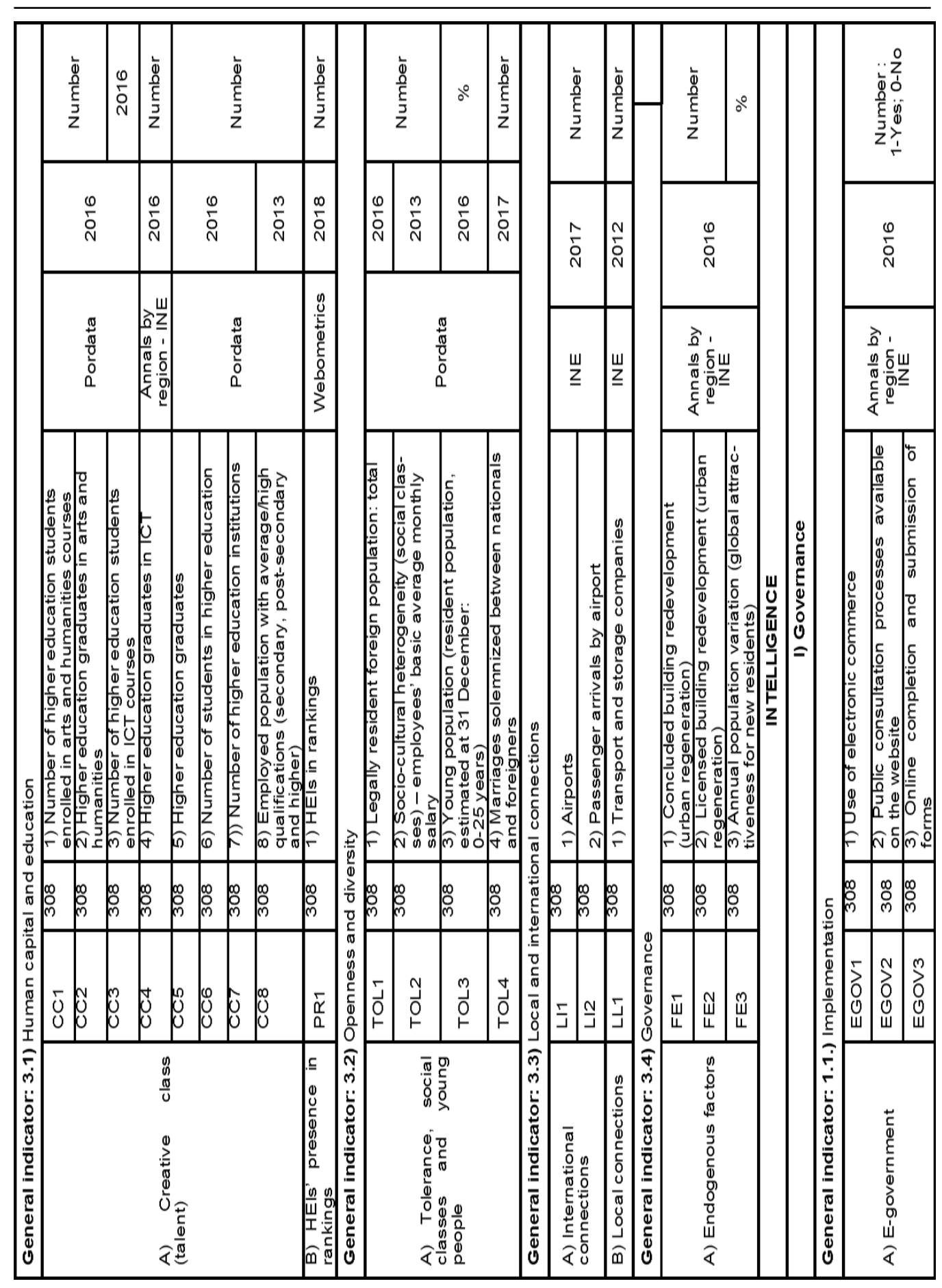




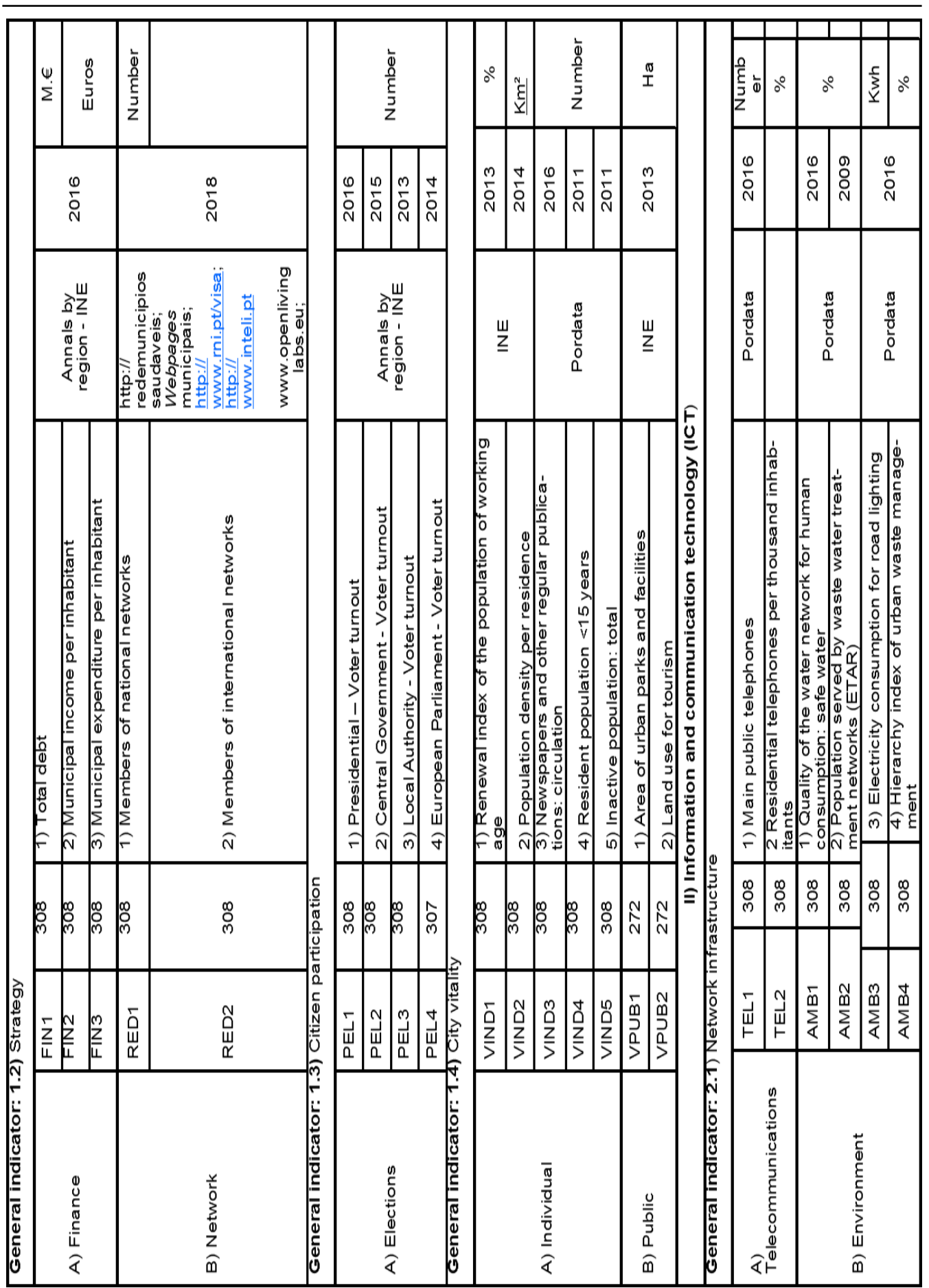


Margarida RODRIGUES, Mário FRANCO

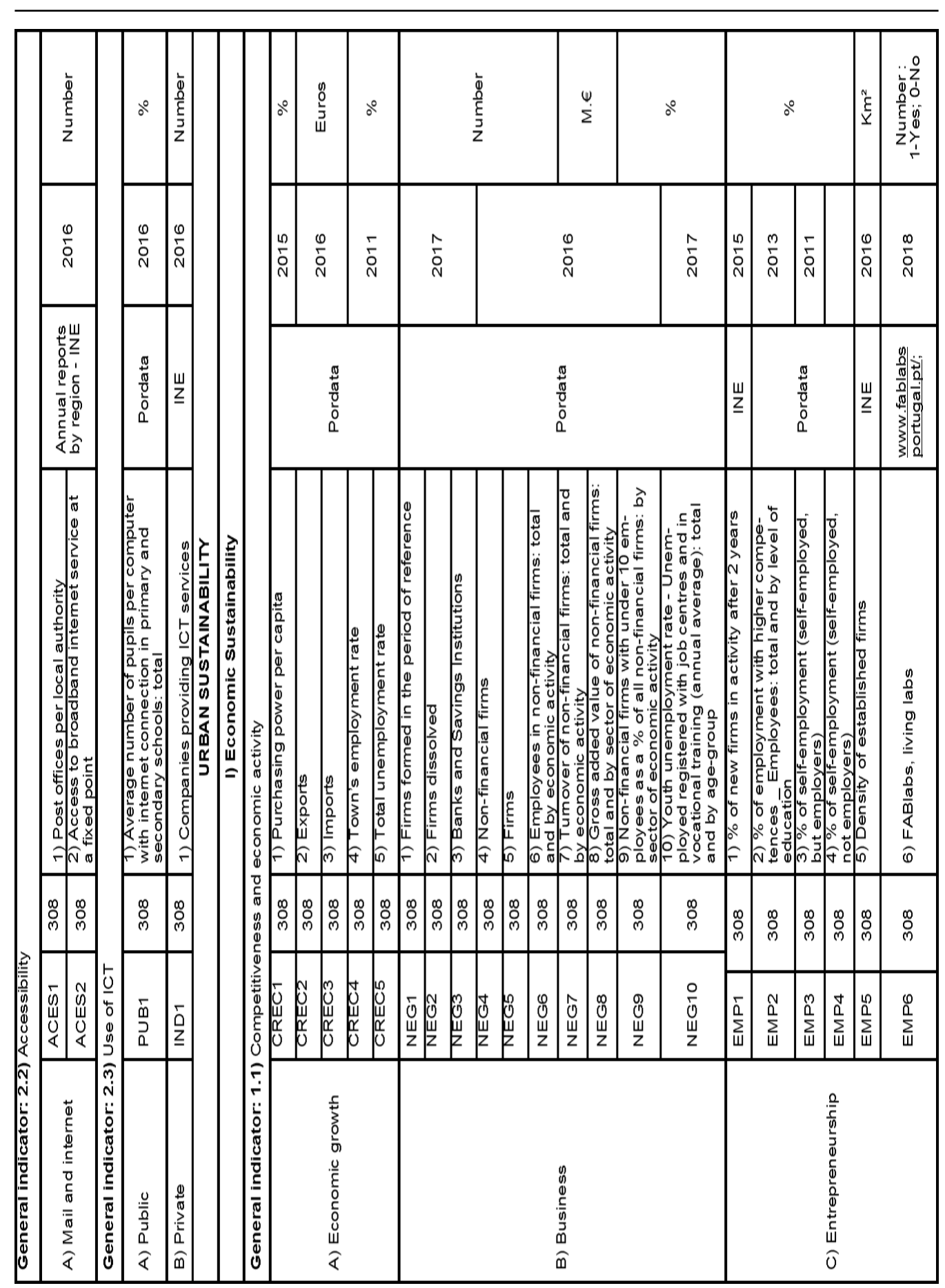




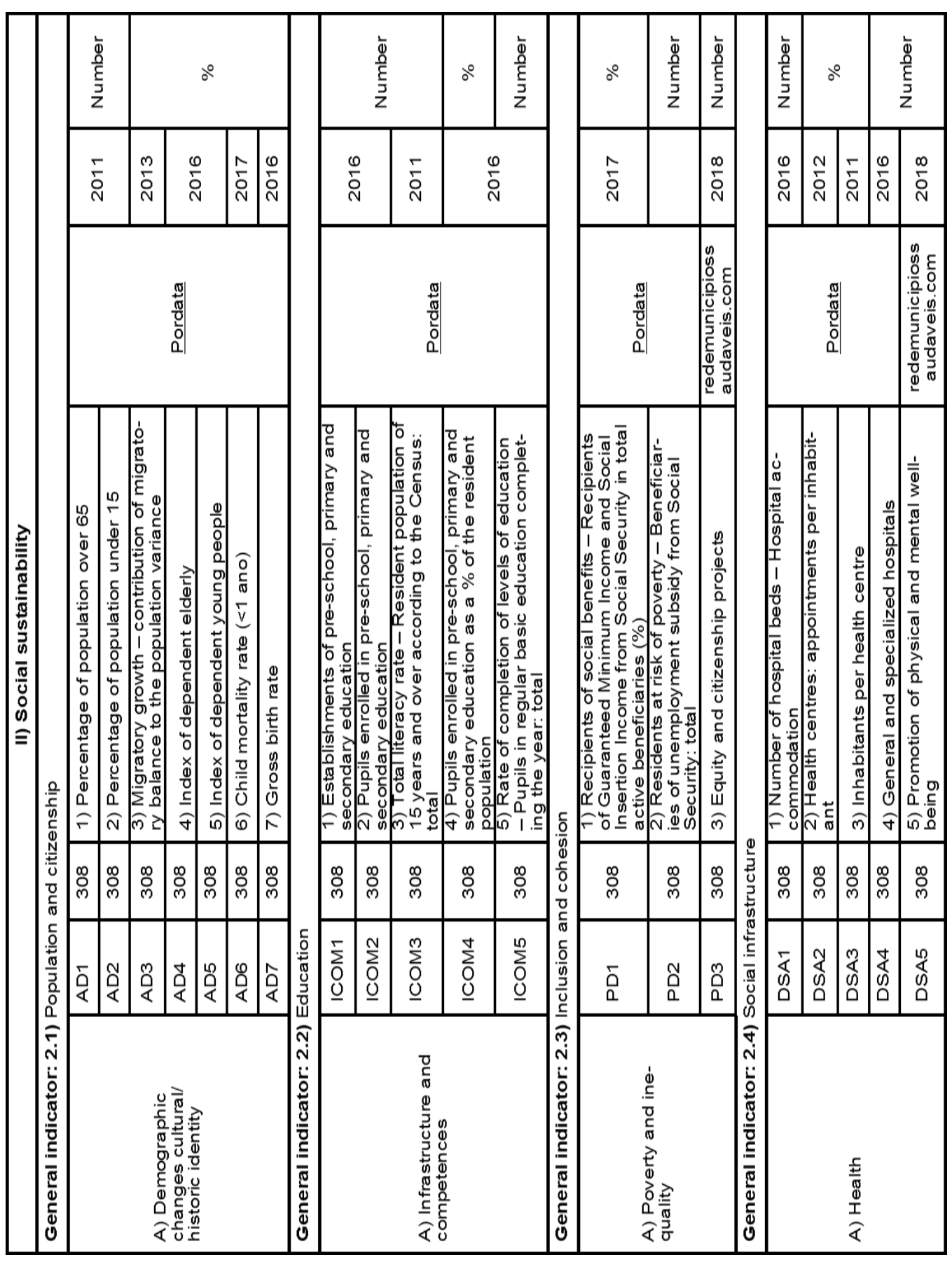


Margarida RODRIGUES, Mário FRANCO

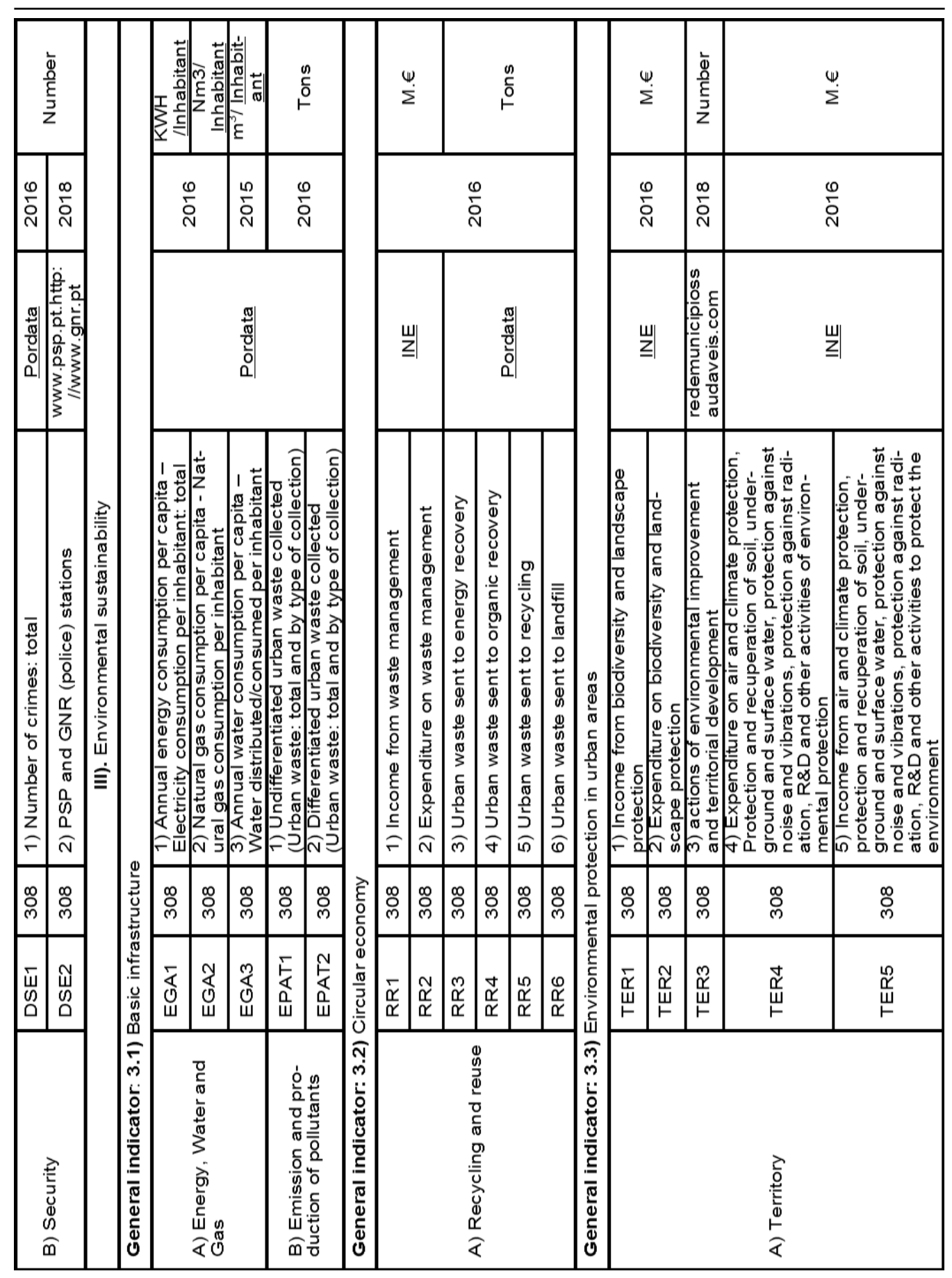


Appendix 2

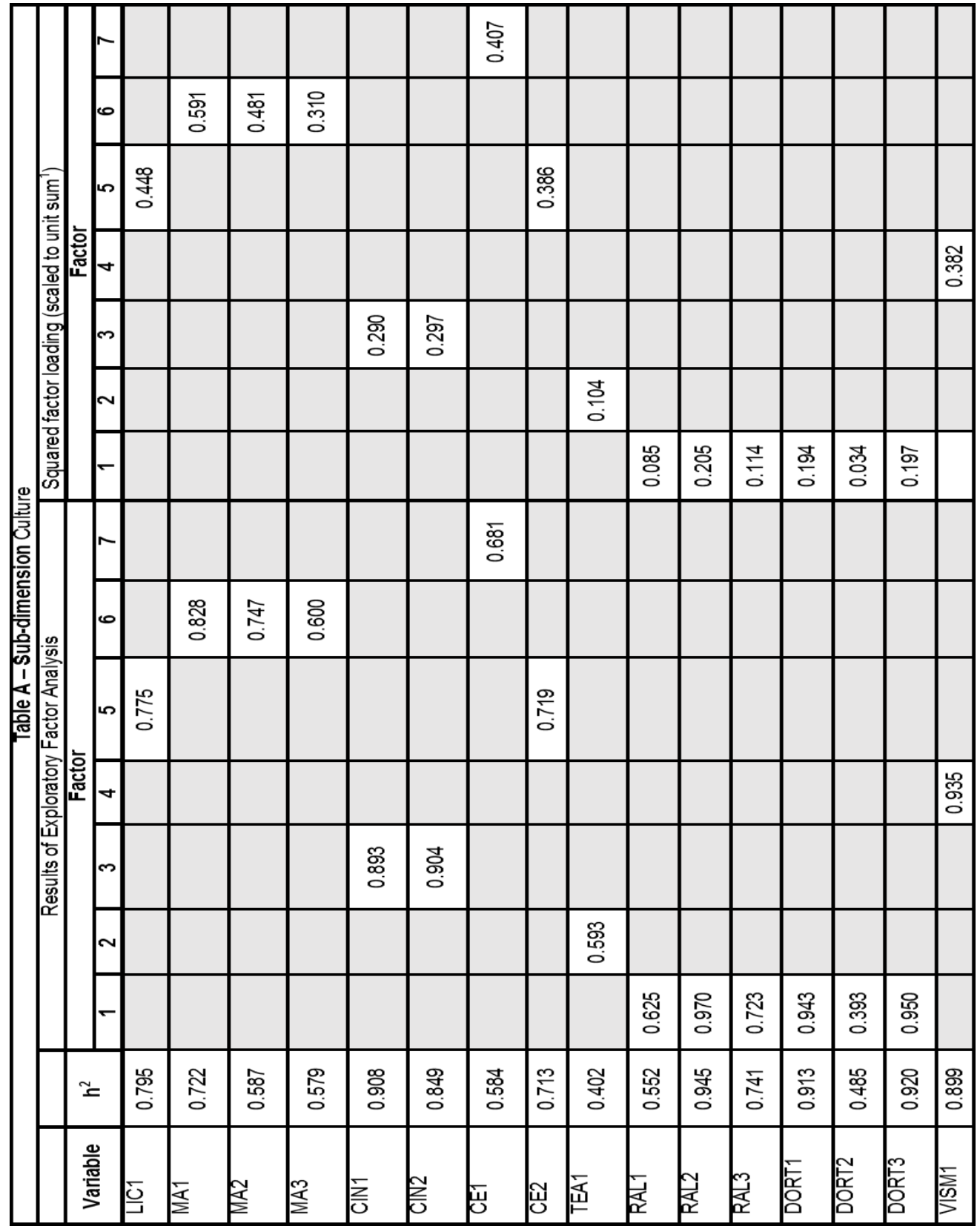

1 Example of calculation for RAL1: $0.625^{\wedge} 2 / 4.59=0.085$ 


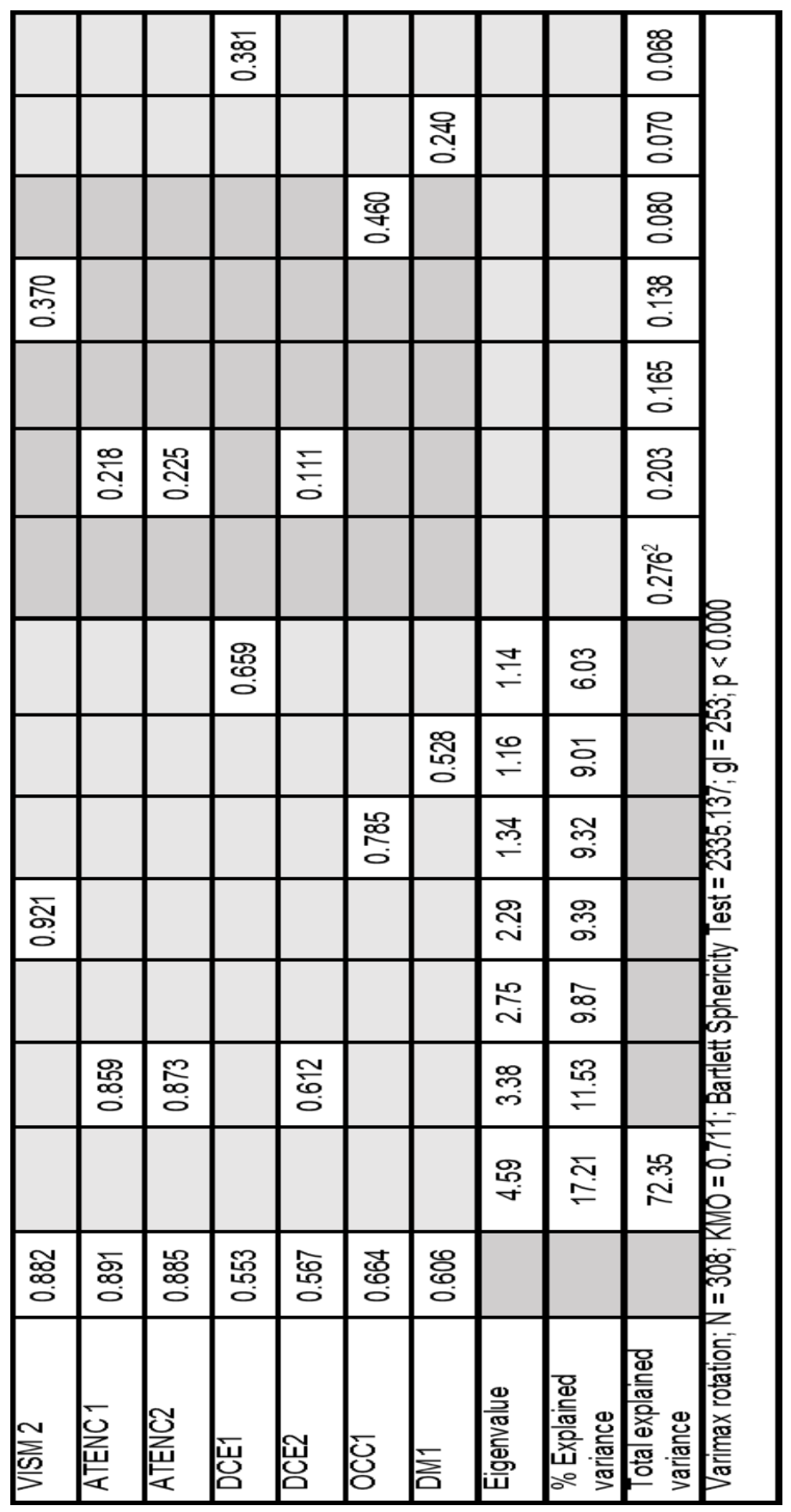

2 Example of calculation for: $4.59 / \sum 4.59+3.38+2.75+2.29+1.34+1.16+1.14=0.276$ 


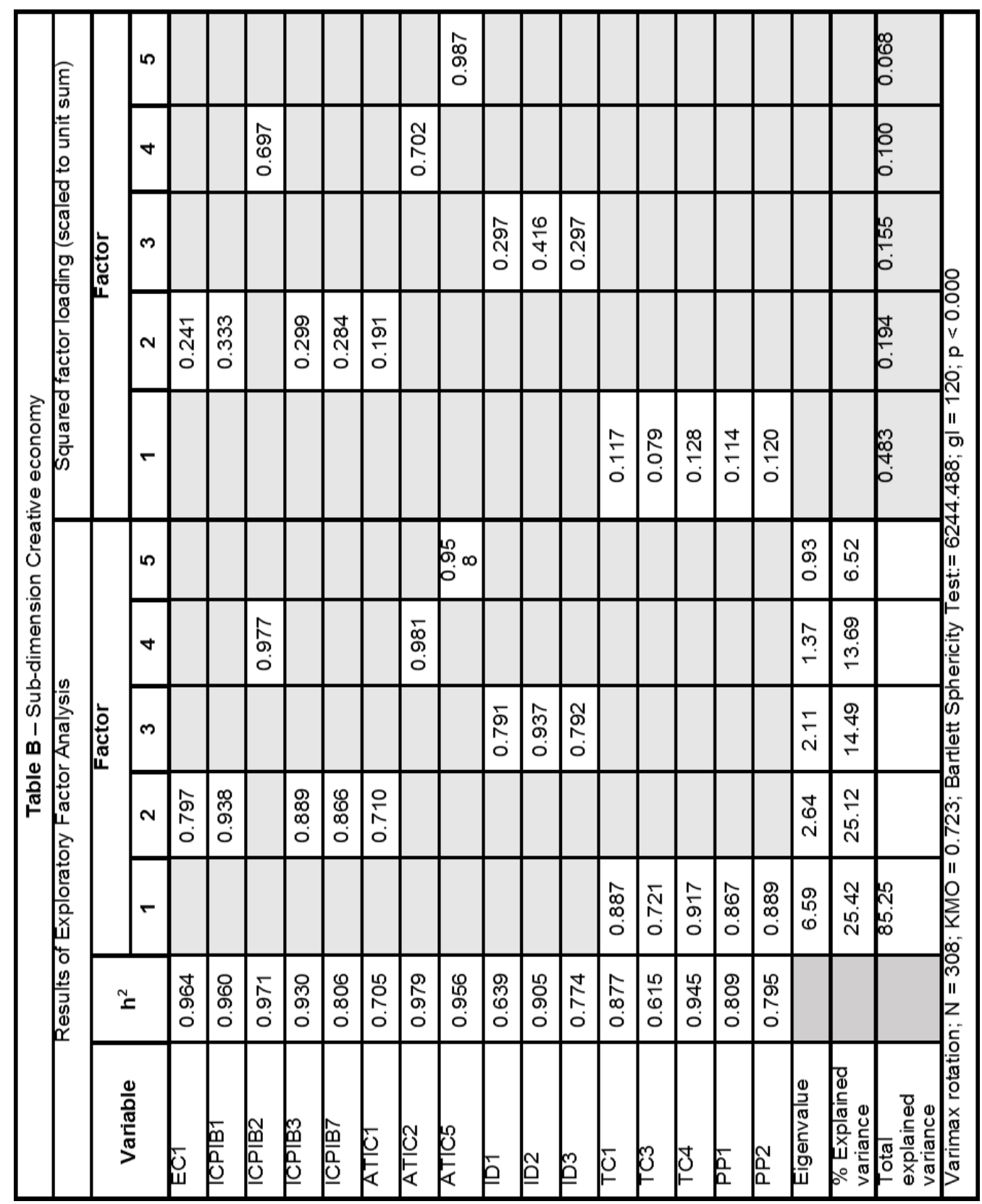




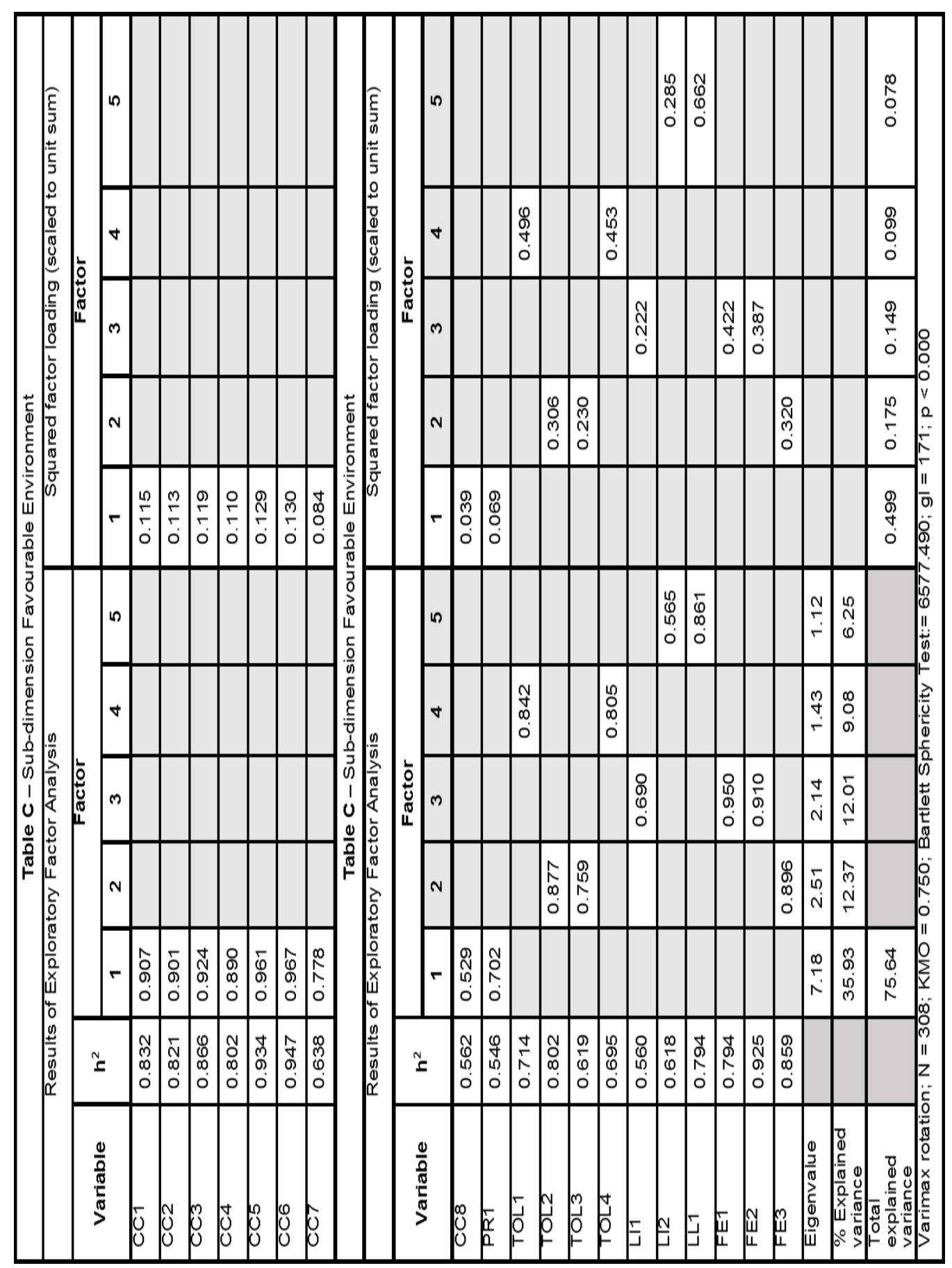


Appendix 3

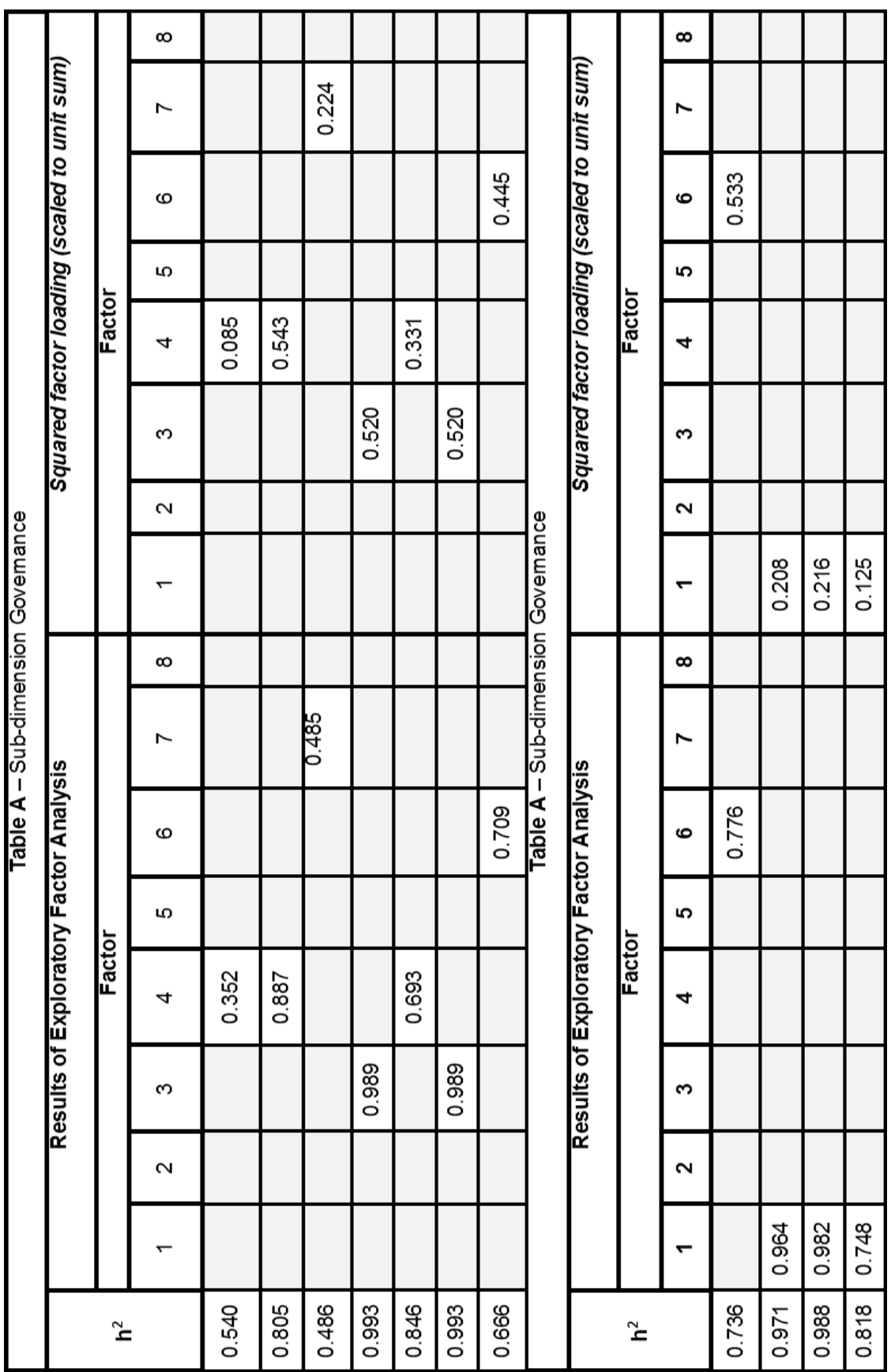


Margarida RODRIGUES, Mário FRANCO

\begin{tabular}{|c|c|c|c|c|c|c|c|c|c|c|c|}
\hline & & & & & & & $\underset{0}{\mathbb{E}}$ & & & 莺 & \\
\hline & & & & & & 㞼 & & & & 兽 & \\
\hline & & & & & & & & & & 音 & \\
\hline & & & 暗 & & & & & & & 흥 & \\
\hline & & 응 & & & & & & & & 영 & \\
\hline & & & & & & & & & & $\stackrel{\overbrace{}}{0}$ & \\
\hline & 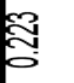 & & & 呑 & $\stackrel{m}{2}$ & & & & & 芯 & \\
\hline ప్ & & & & & & & & & & శ్తి & \\
\hline & & & & & & & $\begin{array}{l}\infty \\
\text { oo } \\
0\end{array}$ & 8: & 은 & & हू \\
\hline & & & & & & 管 & & 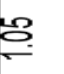 & ్ㅗㅇ & & iI \\
\hline & & & & & & & & $\stackrel{?}{=}$ & 常 & & 8 \\
\hline & & & 敢 & & & & & $\stackrel{\infty}{\stackrel{\infty}{=}}$ & $\frac{\infty}{6}$ & & 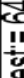 \\
\hline & & 桨 & & & & & & 哭 & 忑 & & 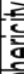 \\
\hline & & & & & & & & $\stackrel{\infty}{=}$ & శ్ & & 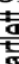 \\
\hline & $\overline{\tilde{g}}$ & & & 惌 & 氖 & & & $\underset{\text { D }}{\vec{D}}$ & 突 & & 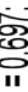 \\
\hline 鸹 & & & & & & & & 年 & $\stackrel{\mathbb{S}}{\mathrm{N}}$ & ్ㅗㅇ & 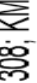 \\
\hline 总 & $\begin{array}{l}\stackrel{2}{8} \\
5\end{array}$ & 苟 & 离 & 㟒 & 唐 & 怘 & $\begin{array}{l}\text { R } \\
\text { O. }\end{array}$ & & & & $\sum_{i=5}^{110}$ \\
\hline 吉 & 高 & 芯 & 䇥 & 营 & 总 & 衰 & 営 & 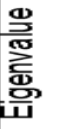 & 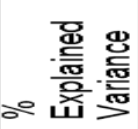 & 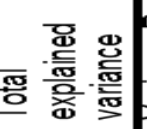 & 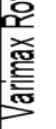 \\
\hline
\end{tabular}




\begin{tabular}{|c|c|c|c|c|c|c|c|c|c|}
\hline \multicolumn{10}{|c|}{ Table B - Sub-dimension ICT } \\
\hline \multirow{3}{*}{ Variable } & \multicolumn{5}{|c|}{$\begin{array}{l}\text { Results of Exploratory Factor } \\
\text { Analysis }\end{array}$} & \multirow{2}{*}{\multicolumn{4}{|c|}{$\begin{array}{l}\text { Squared factor } \\
\text { loading (scaled to } \\
\text { unit sum) } \\
\text { Factor }\end{array}$}} \\
\hline & \multirow{2}{*}{$\mathbf{h}^{2}$} & \multicolumn{4}{|c|}{ Factor } & & & & \\
\hline & & 1 & 2 & 3 & 4 & 1 & 2 & 3 & 4 \\
\hline TEL1 & 0.945 & 0.961 & & & & 0.225 & & & \\
\hline TEL2 & 0.940 & 0.966 & & & & 0.228 & & & \\
\hline AMB1 & 0.935 & & 0.923 & & & & 0.361 & & \\
\hline AMB2 & 0.806 & & 0.877 & & & & 0.326 & & \\
\hline AMB3 & 0.798 & & & 0.863 & & & & 0.683 & \\
\hline AMB4 & 0.970 & & & & 0.953 & & & & 1.032 \\
\hline ACES1 & 0.727 & & & 0.679 & & & & 0.423 & \\
\hline ACES2 & 0.890 & 0.859 & & & & 0.180 & & & \\
\hline PUB1 & 0.781 & & 0.868 & & & & 0.319 & & \\
\hline IND1 & 0.648 & 0.598 & & & & 0.087 & & & \\
\hline Eigenvalue & & 4.10 & 2.36 & 1.09 & 0.88 & & & & \\
\hline $\begin{array}{l}\text { \% Explained } \\
\text { Variance }\end{array}$ & & 40.98 & 23.65 & 10.94 & 8.850 & & & & \\
\hline $\begin{array}{l}\text { Total } \\
\text { explained } \\
\text { variance }\end{array}$ & & 84.41 & 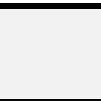 & & & $0.486^{1}$ & 0.280 & 0.129 & 0.104 \\
\hline
\end{tabular}




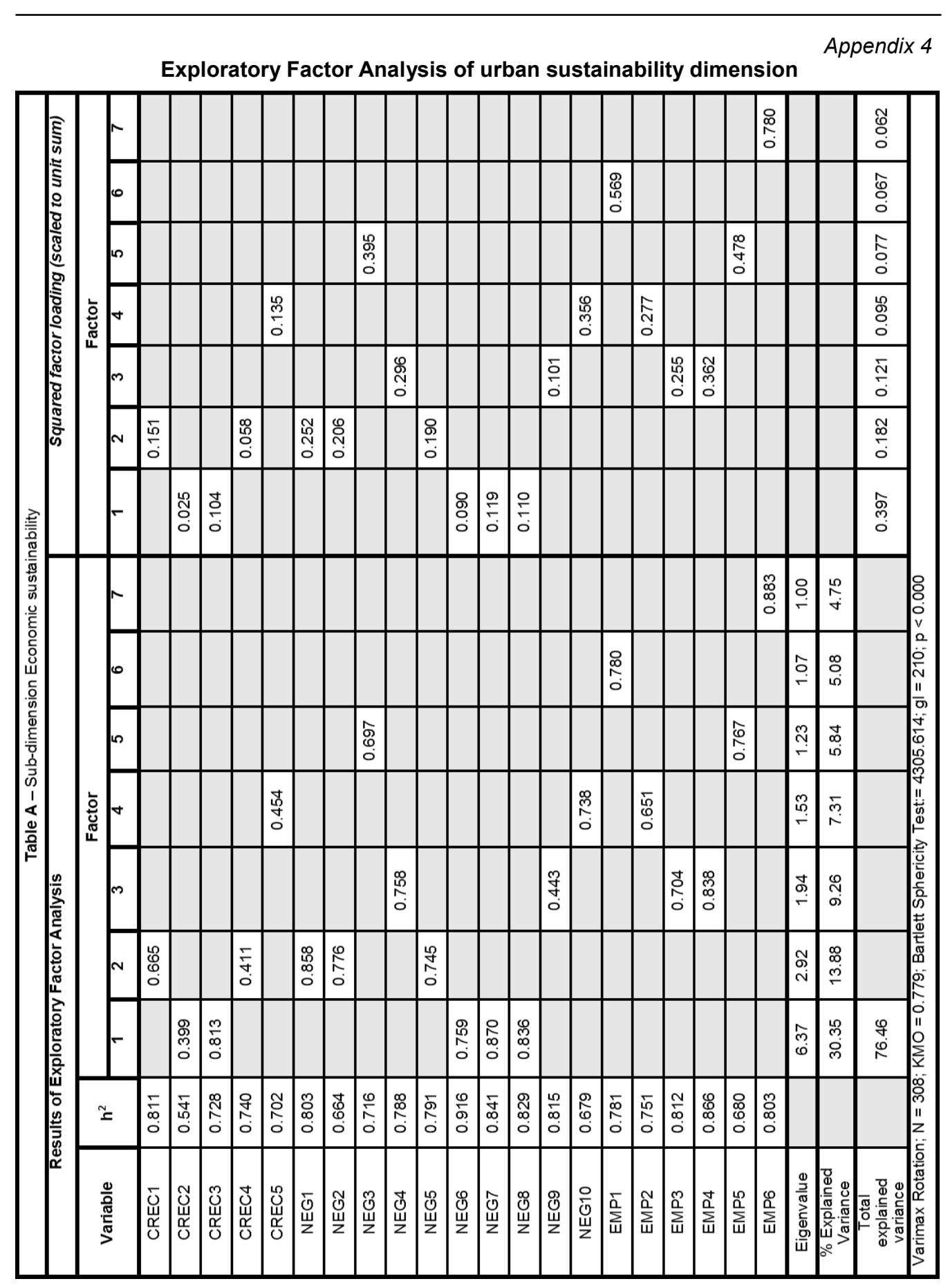




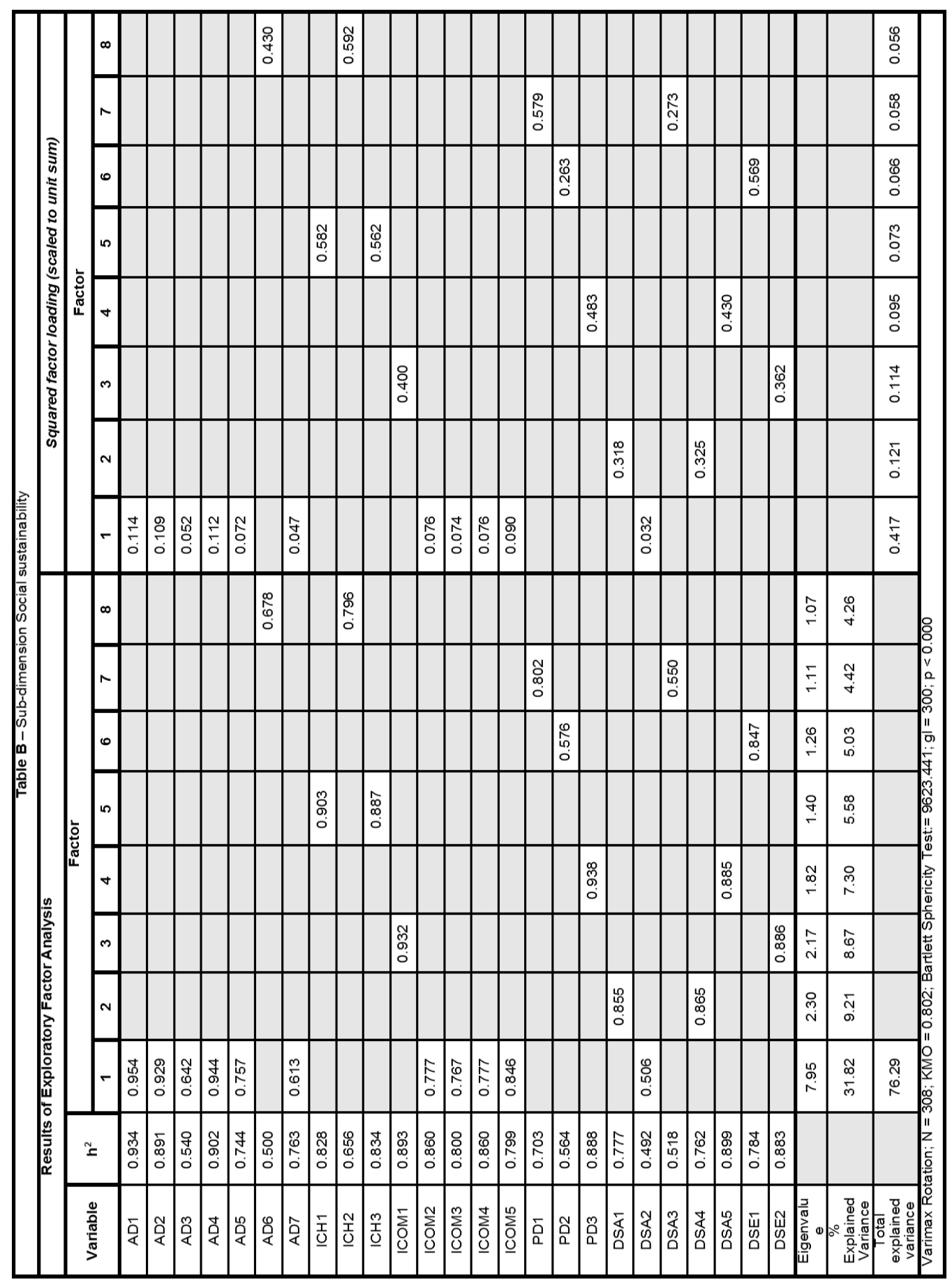




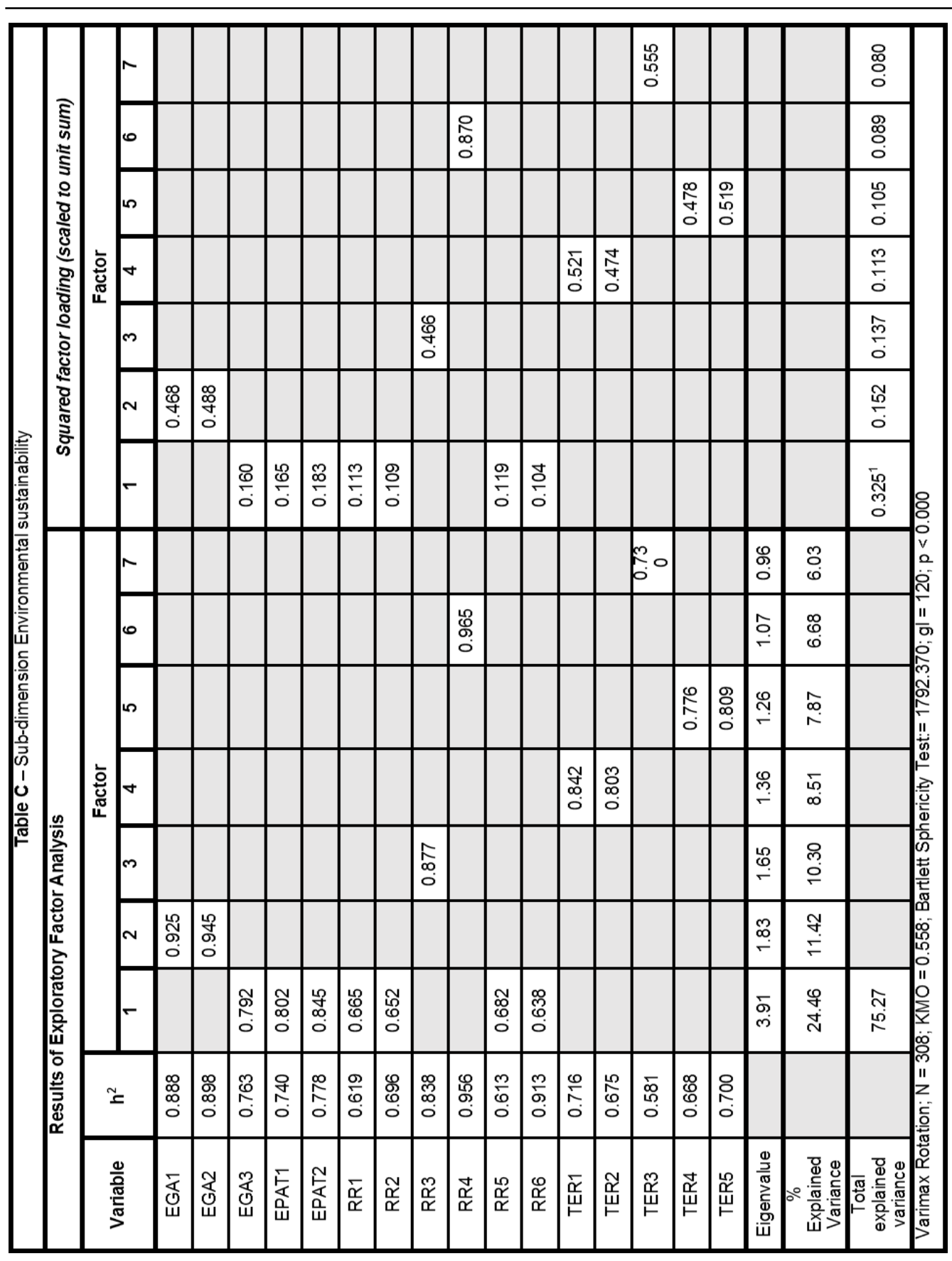

1 Example of calculation: $3.91 / \Sigma 3.91+1.83+1.65+1.36+1.26+1.07+0.96=0.325$ 
Calculation of the weightings of each sub-dimension in the dimension

Appendix 5

Table D - Exploratory Factor Analysis of the Creativity Dimension and Weights

\begin{tabular}{l|r|r|c|}
\hline \multirow{2}{*}{ Subdimensions } & \multirow{2}{*}{$\mathbf{h}^{\mathbf{2}}$} & Factor - Creativity & \multirow{2}{*}{ Weights } \\
\cline { 3 - 3 } & & $\mathbf{1}$ & 0.22 \\
\hline Culture & 0.446 & 0.668 & 0.38 \\
\hline Creative Economy & 0.772 & 0.878 & 0.40 \\
\hline Favourable Environment & 0.810 & 0.900 & 2.03 \\
Eigenvalue & 67.59 \\
\% Explained variance & 67.59 \\
Total explained variance \\
Varimax rotation; $\mathrm{N}=308 ; \mathrm{KMO}=0.607$; Bartlett Sphericity \\
Test:= 299.642: $\mathrm{al}=3: \mathrm{p}<0.000: \mathbf{h}^{2}>67 \%$ : loadinas $>40 \%$
\end{tabular}

Table E - Exploratory Factor Analysis of the Intelligence Dimension and Weights

\begin{tabular}{|l|c|c|c|}
\hline \multirow{2}{*}{ Subdimensions } & \multirow{2}{*}{$\mathbf{h}^{\mathbf{2}}$} & Factor - Intelligence & \multirow{2}{*}{ Weights } \\
\cline { 3 - 3 } & & $\mathbf{1}$ & \\
\hline Governance & 0.566 & 0.752 & 0.50 \\
\hline ICT & 0.566 & 0.752 & 0.50 \\
\hline Eigenvalue & 1.13 & \\
\% Explained variance & 56.55 & \\
Total explained variance & & 56.55 & \\
\hline
\end{tabular}

Varimax Rotation; $\mathrm{N}=308 ; \mathrm{KMO}=0.500 ;$ Bartlett Sphericity

Test:= 5.290; $\mathrm{gl}=1 ; \mathrm{p}<0.000 ; \mathbf{h}^{2}>0.5$ loadings $>0.40$

Table F - Exploratory Factor Analysis of the Urban Sustainability Dimension and Weights

\begin{tabular}{|l|c|c|c|}
\hline \multirow{2}{*}{ Subdimensions } & \multirow{2}{*}{$\mathbf{h}^{\mathbf{2}}$} & $\begin{array}{c}\text { Factor - Urban } \\
\text { Sustainability }\end{array}$ & Weights $^{\mathbf{1}}$ \\
\cline { 3 - 4 } & & $\mathbf{1}$ & \\
\hline Economic sustainability & 0.621 & 0.788 & 0.386 \\
\hline Social sustainability & 0.393 & 0.627 & 0.245 \\
\hline Environmental & 0.593 & 0.770 & 0.369 \\
sustainability & 1.61 & \\
\hline Eigenvalue & 53.60 & \\
\% Explained variance & 53.60 & \\
Total explained variance & &
\end{tabular}

Varimax Rotation; $\mathrm{N}=308 ; \mathrm{KMO}=0.598$; Bartlett Sphericity

Test:= 83.775; $\mathrm{gl}=3 ; \mathrm{p}<0.000 ; \mathbf{h}^{2}>$ or near 0.4 loadings $>0.40$ 


\section{References}

ADNAN Y. M., HAMZAH H., DALI M. M., DAUD M. N., ALIAS A. (2016), An initiativesbased framework for assessing smart city, Planning Malaysia: Journal of the Malaysian Institute of Planners 5, 13-22.

AL SHARMIN A. (2011), A Composite Index to Assess the Regional Development: A Districts-Level analysis, VDM Verlag.

ALBINO V., BERARDI U., DANGELICO R. M. (2015), Smart Cities: Definitions, Dimensions, Performance, and Initiatives, Journal of Urban Technology 22 (1), 3-21.

AMIN A., THRIFT N. (2007), Cultural-economy and cities, Progress in Human Geography 31 (2), 143-161.

ANGELIDOU M. (2017), The Role of Smart City Characteristics in the Plans of Fifteen Cities, Journal of Urban Technology 24 (4), 3-28.

ANTHOPOULOS L. (2017), Smart utopia VS smart reality: Learning by experience from 10 smart city cases, Cities 63, 128-148.

ARCADIS (2016), Sustainable Cities Index 2016: Putting people at the heart of city sustainability, Arcadis, Retrieved from: www.arcadis.com/SCI2016.

ARTMANN M., KOHLER M., MEINEL G., GAN J., IOJA I. C. (2019), How smart growth and green infrastructure can mutually support each other - A conceptual framework for compact and green cities, Ecological Indicators 96 (2), 10-22.

ATABEK A., COȘAR E. E., ŞAHINÖZ S. (2005), A new composite leading indicator for Turkish economic activity, Emerging Markets Finance \& Trade 41 (1), 45-64.

AUDRETSCH D. B. (2003), Managing knowledge spillovers: the role of geographic proximity, in: Baum J. A. C., Sorenson O. (eds.), Geography and Strategy (Advances in Strategic Management, Vol. 20), Emerald Group Publishing Limited, Bingley, pp. 23-48.

BIBRI S. E., KROGSTIE J. (2017), On the social shaping dimensions of smart sustainable cities: A study in science, technology, and society, Sustainable Cities and Society 29, 219-246.

BIFULCO F., TREGUA M., AMITRANO C. C. (2017), Co-governing smart cities through living labs. Top evidences from EU, Transylvanian Review of Administrative Sciences 50, 21 37.

BLOOM CONSULTING (2017), Portugal City Brand Ranking 2016, Bloom Consulting, 156, Retrieved from: www.bloom-consulting.com

BORÉN T., YOUNG C. (2013), Getting creative with the 'Creative City'? Towards new perspectives on creativity in urban policy, International Journal of Urban and Regional Research 37 (5), 1799-1815.

BORSEKOVA K., KORÓNY S., VAŇOVÁ A., VITÁLIŠOVÁ K. (2018), Functionality between the size and indicators of smart cities: A research challenge with policy implications, Cities 78, 17-26.

BOSCH P., JONGENEEL S., ROVERS V., NEUMANN H.-M., AIRAKSINEN M., HUOVILA A. (2017), CITYkeys indicators for smart city projects and smart cities, CITYkeys, Retrieved from: www.citykeys-project.eu.

BOUK S. H., AHMED S. H., KIM D., SONG H. (2017), Named-Data-Networking-Based ITS for Smart Cities, IEEE Communications Magazine 55 (1), 105-111.

BOUTON S., CIS D., MENDONCA L., POHL H., REMES J., RITCHIE H., WOETZEL J. (2013), How to make a city great: A review of the steps city leaders around the world take to transform their cities into great places to live and work, McKinsey \& Company, Retrieved from: www.mckinsey.com.

CABRITA M. D. R., CRUZ-MACHADO V., CABRITA C. (2013), Managing creative industries in the context of knowledge-based urban development, International Journal of Knowledge-Based Development 4 (4), 318-337.

CAMAGNI R., CAPELLO R., NIJKAMP P. (1998), Towards sustainable city policy: an economy-environment technology nexus, Ecological Economics 24 (1), 103-118. 
CARAGLIU A., DEL BO C., NIJKAMP P. (2011), Smart cities in Europe, Journal of Urban Technology 18 (2), 65-82.

CARLI R., DOTOLI M., PELLEGRINO R., RANIERI L. (2013), Measuring and managing the smartness of cities: a framework for classifying performance indicators, IEEE International Conference on Systems, Management, and Cybernetics, 1288-1293.

CARTA M. (2009), Culture, communication and cooperation: the three Cs for a proactive creative city, International Journal of Sustainable Development 12 (2-4), 124-133.

CASTRO-HIGUERAS A., DE AGUILERA-MOYANO M. (2018), Assessing creativity: an index proposal, Creative Industries Journal 11 (1), 102-118.

CAVALCANTI C. (1995), Sustentabilidade da economia: paradigmas alternativos de realização econômica, in: Cavalcanti C. (ed.), Desenvolvimento e natureza: estudos para uma sociedade sustentável, Cortez, São Paulo, pp. 153-174.

ÇETINDAMAR D., GÜNSEL A. (2012), Measuring the Creativity of a City: A Proposal and an Application, European Planning Studies 20 (8), 1301-1318.

CHANG D. L., SABATINI-MARQUES J., DA COSTA E. M., SELIG P. M., YIGITCANLAR T. (2018), Knowledge-based, smart and sustainable cities: a provocation for a conceptual framework, Journal of Open Innovation: Technology, Market, and Complexity 4 (5), $1-17$.

COHEN B., ALMIRALL E., CHESBROUGH H. (2016), The city as a lab: open innovation meets the collaborative economy, California Management Review 59 (1), 5-13.

COSTELLO A. B., OSBORNE J. W. (2005), Best Practices in Exploratory Factor Analysis: Four Recommendations for Getting the Most From Your Analysis, Practical Assessment, Research \& Evaluation 10 (7), 1-9.

DANIELIS R., ROTARIS L., MONTE A. (2018), Composite indicators of sustainable urban mobility: Estimating the rankings frequency distribution combining multiple methodologies, International Journal of Sustainable Transportation 12 (5), 380-395.

DAVOUDI S., STURZAKER J. (2017), Urban form, policy packaging and sustainable urban metabolism, Resources, Conservation and Recycling, 120, 55-64.

DELLA LUCIA M., TRUNFIO M., GO F. M. (2017), Heritage and Urban Regeneration: Towards Creative Tourism, in: Bellini N., Pasquinelli C. (eds.), Tourism in the City, Springer, Cham, pp. 179-191.

DEVOL R., RATNATUNGA M., BEDROUSSIAN A. (2015), 2014 Best-Performing Cities: Where America's jobs are created and sustained, Milken Institute, Retrieved from: www.best-cities.org.

DHINGRA M., CHATTOPADHYAY S. (2016), Advancing smartness of traditional settlements-case analysis of Indian and Arab old cities, International Journal of Sustainable Built Environment 5 (2), 549-563.

DODGSON M., GANN D. (2011), Technological Innovation and Complex Systems in Cities, Journal of Urban Technology 18 (3), 101-113.

DONEGAN M., LOWE N. (2008), Inequality in the Creative City: Is There Still a Place for "Old-Fashioned" Institutions?, Economic Development Quarterly 22 (1), 46-62.

DURMAZ B., PLATT S., YIGITCANLAR T. (2010), Creative, culture tourism and placemaking: Istanbul and London film industries, International Journal of Culture, Tourism and Hospitality Research 4 (3), 198-213.

ECHEBARRIA C., BARRUTIA J. M., AGUADO I., APAOLAZA V., HARTMANN P. (2016), Capturing the benefits that emerge from regional sustainability networks: The CastileLa Mancha network of sustainable cities and towns, Papers in Regional Science 95 (S1), S27S49.

EL GIBARI S., GÓMEZ T., RUIZ F. (2018), Building composite indicators using multicriteria methods: a review, Journal of Business Economics 89, 1-24.

ELKINGTON J. (2004), Enter the triple bottom line, in: Henriques A., Richardson J. (eds.), The triple bottom line: Does it all add up?, Earthscan, New York, pp. 1-16.

EPA (2016), Framework for Creating a Smart Growth Economic Development Strategy: 
a Tool for Small Cities and Towns, U.S. Environmental Protection Agency, Retrieved from: www.epa.gov.

ERICSSON (2016), Networked Society City Index 2016: Cities play key role in sustainable development, Retrieved from: www.ericsson.com.

EUROPEAN COMMISSION (2011), Cities of tomorrow: Challenges, visions, ways forward, Publications Office of the European Union, Luxembourg.

EUROPEAN COMMISSION (2019), Reference framework for sustainable cities, Retrieved from: www.rfsc.eu.

EUROSTAT (2019), Smarter, greener, more inclusive? Indicators to support the Europe 2020 strategy - 2019 edition, Publications Office of the European Union, Luxembourg.

EY (2016), Smart city index 2016 Report, Retrieved from: www.ey.com.

FERRARIS A., SANTORO G., PAPA A. (2018), The cities of the future: Hybrid alliances for open innovation projects, Futures 103, 51-60.

FLORES L. E. B., TEIXEIRA C. S. (2017), Cidades Sustentáveis e Cidades Inteligentes: Uma análise dos rankings Arcadis e European smart cities, Revista Eletrônica do Alto Vale do Itajaí 6 (9), 68-76.

FLORIDA R. (2005), Cities and the creative class, Routledge, New York and London.

FLORIDA R. (2019), The Rise of the Creative Class: And How It's Transforming Work, Leisure, Community, and Everyday Life, Basic Books, New York.

FLORIDA R., MELLANDER C., STOLARICK K. (2007), Inside the black box of regional development-human capital, the creative class and tolerance, Journal of Economic Geography 8, 615-649.

FPA (2017), ICity rate 2017: Le città più smart sono quelle più vicine ai target globali di sviluppo sostenibile, Retrieved from: www.profilo.forumpa.it.

FURTADO G., ALVES S. (2012), Cidades criativas em Portugal e o papel da arquitetura: Mais uma estratégia a concertar, Revista Crítica de Ciências Sociais 99, 125-140.

GARAU C., BALLETTO G., MUNDULA L. (2017), A Critical Reflection on Smart Governance in Italy: Definition and Challenges for a Sustainable Urban Regeneration, in: Bisello A., Vettorato D., Stephens R., Elisei P. (eds.), Smart and Sustainable Planning for Cities and Regions, SSPCR 2015. Green Energy and Technology, Springer, Cham, pp. 235250.

GARCÍA SUÁREZ J. A., PULIDO FERNÁNDEZ J. I. (2015), Creacity, una propuesta de índice para medir la creatividad turística. Aplicación en tres destinos urbano-culturales españoles, Revista de Estudios Regionales 103, 69-108.

GIFFINGER R., FERTNER C., KRAMAR H., KALASEK R., PICHLER- MILANOVIĆ N., MEIJERS E. (2007), Smart cities. Ranking of European medium-sized cities, Centre of Regional Science, Vienna, Retrieved from: www.smart-cities.eu.

GIRARD L. F., BAYCAN T., NIJKAMP P. (2016), Sustainable City and Creativity: Promoting Creative Urban Initiatives, Routledge, New York and London.

GRANT J. L., KRONSTAL K. (2010), The social dynamics of attracting talent in Halifax, The Canadian Geographer 54 (3), 347-365. Hamburg.

GUIMARÃES R. C., SARSFIELD CABRAL J. A. (2010), Estatística, Verlag Dashöfer,

HABERSTROH M. M., PINKWART A. (2018), Increasing the Innovative Capacity of European Cities: Making Use of Proven Concepts from the National Level, in: Albach H., Meffert H., Pinkwart A., Reichwald R., Swiątczak Ł. (eds.), European Cities in Dynamic Competition, Springer, Berlin, pp. 19-53.

HAIR JR. J. F., BLACK W. C., BABIN B. J., ANDERSON R. E. (2014), Multivariate data analysis, Pearson, Harlow.

HARTLEY J., POTTS J., MACDONALD T., ERKUNT C., KUFLEITNER C. (2012), Creative city index, Cultural Science Journal 5 (1), 1-138.

HOLLANDS R. G. (2008), Will the real smart city please stand up? Intelligent, progressive or entrepreneurial?, City 12 (3), 303-320. 
HOSPERS G.-J., PEN C.-J. (2008), A View on Creative Cities Beyond the Hype, Creativity and Innovation Management 17 (4), 259-270.

HOYMAN M., FARICY C. (2009), It Takes a Village: A Test of the Creative Class, Social Capital, and Human Capital Theories, Urban Affairs Review 44 (3), 311-333.

HUOVILA A., AIRAKSINEN M., PINTO-SEPPÄ I., PIIRA K., BOSCH P., PENTTINEN T., NEUMANN H.-M., KONTINAKIS N. (2017), CITYkeys Smart city performance measurement system, International Journal for Housing Science 41 (2), 113-125.

ISO (2018), ISO 37120:2018 Sustainable cities and communities - Indicators for city services and quality of life, Retrieved from: www.iso.org.

IRUNGBAM R. S. (2016), The Model of Smart Cities in Theory and in Practice, Journal for Studies in Management and Planning 2 (4), 156-169.

JOSS S., COWLEY R., TOMOZEIU D. (2013), Towards the 'ubiquitous eco-city': An analysis of the internationalisation of eco-city policy and practice, Urban Research \& Practice 6 (1), 54-74.

KAISER H. F. (1974), An index of factorial simplicity, Psychometrika 39 (1), 31-36.

KAKIUCHI E. (2016), Culturally creative cities in Japan: Reality and prospects, City, Culture and Society 7 (2), 101-108.

KL'ÚČIK M., HALUŠKA J. (2008), Construction of Composite Leading Indicator for the Slovak Economy, Scientific Annals of Economics and Business 55, 363-370.

KONG L. (2014), From cultural industries to creative industries and back? Towards clarifying theory and rethinking policy, Inter-Asia Cultural Studies 15 (4), 593-607.

KUBRUSLY L. S. (2001), Um procedimento para calcular índices a partir de uma base de dados multivariados, Pesquisa Operacional 21 (1), 107-117.

LANDRY C. (2012), The creative city: A toolkit for urban innovators, Earthscan, London.

LAWTON P., MURPHY E., REDMOND D. (2010), Examining the role of 'creative class' ideas in urban and economic policy formation: the case of Dublin, Ireland, International Journal of Knowledge-Based Development 1 (4), 267-286.

LEE J. H., HANCOCK M. G., HU M.-C. (2014), Towards an effective framework for building smart cities: Lessons from Seoul and San Francisco, Technological Forecasting and Social Change 89, 80-99.

LETAIFA S. B. (2015), How to strategize smart cities: Revealing the SMART model, Journal of Business Research 68 (7), 1414-1419.

LIGORIO V. (2017), New economic development pattern: from a linear to a circular economy, a challenge for EU's economy, International Scientific Journal “Internauka” 1 (23), 20 $-23$.

LOMBARDI P., GIORDANO S., FAROUH H., YOUSEF W. (2012), Modelling the smart city performance, Innovation: The European Journal of Social Science Research 25 (2), 137 149.

MADEIRA G., GUIMARAES T., MENDES L. D. S. (2016), Assessing some models for city e-government implementation: a case study, Electronic Government 12 (1), 86-105.

MALECKI E. J. (2007), Cities and regions competing in the global economy: knowledge and local development policies, Environment and Planning C: Government and Policy 25 (5), 638-654.

MARDIKYAN S., YILDIZ E. A., ORDU M. D., ŞIMŞEK B. (2015), Examining the Global Digital Divide: A Cross-Country Analysis, Communications of the IBIMA, 1-10. Pinheiro.

MARÔCO J. (2018), Análise estatística com o SPSS Statistics, Report Number, Pêro

MCGRANAHAN D., WOJAN T. (2007), Recasting the Creative Class to Examine

Growth Processes in Rural and Urban Counties, Regional Studies 41 (2), 197-216.

MEGA V., PEDERSEN J. (1998), Urban Sustainability Indicators, Office for Official Publications of the European Communities, Luxembourg.

MONTALTO V., TACAO MOURA C., PANELLA F., ALBERTI V., BECKER W., SAISANA M. (2019), The Cultural and Creative Cities Monitor: 2019 Edition, Publications Office 
of the European Union, Luxembourg.

MORA L., BOLICI R., DEAKIN M. (2017), The First Two Decades of Smart-City Research: A Bibliometric Analysis, Journal of Urban Technology 24 (1), 3-27.

NAM T., PARDO T. A. (2011), Smart city as urban innovation: focusing on management, policy, and context, Proceedings of the 5th International Conference on Theory and Practice of Electronic Governance, 185-194.

NARDO M., SAISANA M., SALTELLI A., TARANTOLA S. (2005), Tools for composite indicators building, Joint Research Centre. European Commission, Retrieved from: www.publications.jrc.ec.europa.eu.

NEIROTTI P., DE MARCO A., CAGLIANO A. C., MANGANO G., SCORRANO F.

(2014), Current trends in Smart City initiatives: Some stylised facts, Cities 38, 25-36.

NIJKAMP P., KOURTIT K. (2013), The "New Urban Europe": Global Challenges and Local Responses in the Urban Century, European Planning Studies 21 (3), 291-315. OECD (2008), Handbook on Constructing Composite Indicators: Methodology and Userguide, OECD Publications, Paris.

ORTEGEL M. (2017), "Creative city" policy mobilities as transformation of dispositives - arrangements of "networking" in the European Metropolitan Region of Nuremberg, Geographica Helvetica 72 (2), 157-169.

PANAL G. G., YÁÑEZ C. N. (2012), Industrias culturales en ciudades españolas. Un primer acercamiento, Revista de Estudios Regionales 94, 71-103.

PARTRIDGE H. (2004), Developing a Human Perspective to the Digital Divide in the Smart City, Proceedings of Alia 2004 Challenging Ideas, 1-7.

PESTANA M. H., GAGEIRO J. N. (2014), Análise de dados para ciências sociais: a complementaridade do SPSS, Edições Sílabo, Lisbon.

PICARD R. G., GRÖNLUND M., TOIVONEN T. (2003), Means for overall assessment of cultural life and measuring the involvement of the cultural sector in the information society, Publications of the Ministry of Education Finland, Helsinki.

PITUCH K. A., STEVENS J. P. (2016), Applied multivariate statistics for the social sciences, Routledge, New York and London.

POWER D., SCOTT A. J. (2011), Culture, creativity, and urban development, in: Pike A., Rodríguez-Pose A., Tomaney J. (eds.), Handbook of Local and Regional Development, Routledge, New York and London, pp. 162-171.

POZDNIAKOVA A. (2017), Smart sustainable cities: the concept and approaches to measurement, Acta Innovations 22, 5-19.

PRATT A. C. (2008), Creative cities: the cultural industries and the creative class, Geografiska Annaler: Series B, Human Geography 90 (2), 107-117.

PRIANO F. H., GUERRA C. F. (2014), A framework for measuring smart cities, Proceedings of the 15th Annual International Conference on Digital Government Research, 44 -54 .

RAHBARIANYAZD R., DORATLI N. (2017), Assessing the contribution of cultural agglomeration in urban regeneration through developing cultural strategies, European Planning Studies 25 (10), 1714-1733.

RATIU D. E. (2013), Creative cities and/or sustainable cities: Discourses and practices, City, Culture and Society 4 (3), 125-135.

RATTEN V. (2017), Entrepreneurship, Innovation and Smart Cities, Routledge, New Work and London.

RODRIGUES M., FRANCO M. (2018), Measuring the Performance in Creative Cities: Proposal of a Multidimensional Model, Sustainability 10 (11), 1-21.

RODRIGUES M., FRANCO M. (2019a), Measuring cities' performance: Proposal of a Composite Index for the intelligence dimension, Measurement 139, 112-121.

RODRIGUES M., FRANCO M. (2019b), Composite index to measure cities' creative performance: An empirical study in the Portuguese context, Sustainability 11 (3), 774.

ROMEIN A., TRIP J. J. (2009), Key elements of creative city development: An assessment of local policies in Amsterdam and Rotterdam, City Futures '09, 1-19. 
ROMERO-PADILLA Y., NAVARRO-JURADO E., MALVÁREZ-GARCÍA G. (2016), The potential of international coastal mass tourism destinations to generate creative capital, Journal of Sustainable Tourism 24 (4), 574-593.

SAISANA M., TARANTOLA S. (2002), State-of-the-art Report on Current Methodologies and Practices for Composite Indicator Development, Joint Research Centre. European Commission, Retrieved from: www.publications.jrc.ec.europa.eu.

SCOTT A. J. (2000), The cultural economy of cities: essays on the geography of imageproducing industries, SAGE Publications Ltd, London.

SCOTT A. J. (2006), Creative cities: Conceptual issues and policy questions, Journal of Urban Affairs 28 (1), 1-17.

SHAPIRO J. M. (2006), Smart Cities: Quality of Life, Productivity, and the Growth Effects of Human Capital, The Review of Economics and Statistics 88 (2), 324-335.

SKAVRONSKA I. V. (2017), Creative industries in Ukraine: Analysis and prospects of the development, Economics and Sociology 10 (2), 87-106.

SMOL M., KULCZYCKA J., AVDIUSHCHENKO A. (2017), Circular economy indicators in relation to eco-innovation in European regions, Clean Technologies and Environmental Policy 19 (3), 669-678.

STANICKOVA M., MELECKÝ L. (2018), Understanding of resilience in the context of regional development using composite index approach: the case of European Union NUTS-2 regions, Regional Studies. Regional Science 5 (1), 231-254.

York.

TABACHNICK B. G., FIDELL L. S. (2019), Using multivariate statistics, Pearson, New

TRANOS E., GERTNER D. (2012), Smart networked cities?, Innovation: The European Journal of Social Science Research 25 (2), 175-190.

TRIVELLATO B. (2016), How can 'smart' also be socially sustainable? Insights from the case of Milan, European Urban and Regional Studies 24 (4), 337-351.

U4SSC (2017), Collection Methodology for Key Performance Indicators for Smart Sustainable Cities, Geneva.

WALKER R. M., HILLS P. (2012), Partnership Characteristics, Network Behavior, and Publicness: Evidence on the Performance of Sustainable Development Projects, International Public Management Journal 15 (4), 479-499.

WHEELER S. M., BEATLEY T. (2014), The Sustainable Urban Development Reader, Routledge, London and New York.

Initial submission: 20.03.2019

Revised submission: 30.09 .2019

Final acceptance: 23.10 .2019

Correspondence: Management and Economics Department, University of Beira Interior, CEGAGE-UBI Research Center, Estrada do Sineiro, 6200-209 Covilhã, Portugal.

Email: mfranco@ubi.pt 
